\title{
KARST AS A CRITERION FOR DEFINING AREAS LESS SUITABLE FOR AGRICULTURE
}

\section{KRAS KOT KAZALNIK ZA DOLQČANJE MANJ PRIMERNIH OBMOCIJ ZA KMETIJSTVO}

Rok Ciglič, Mauro Hrvatin, Blaž Komac, Drago Perko

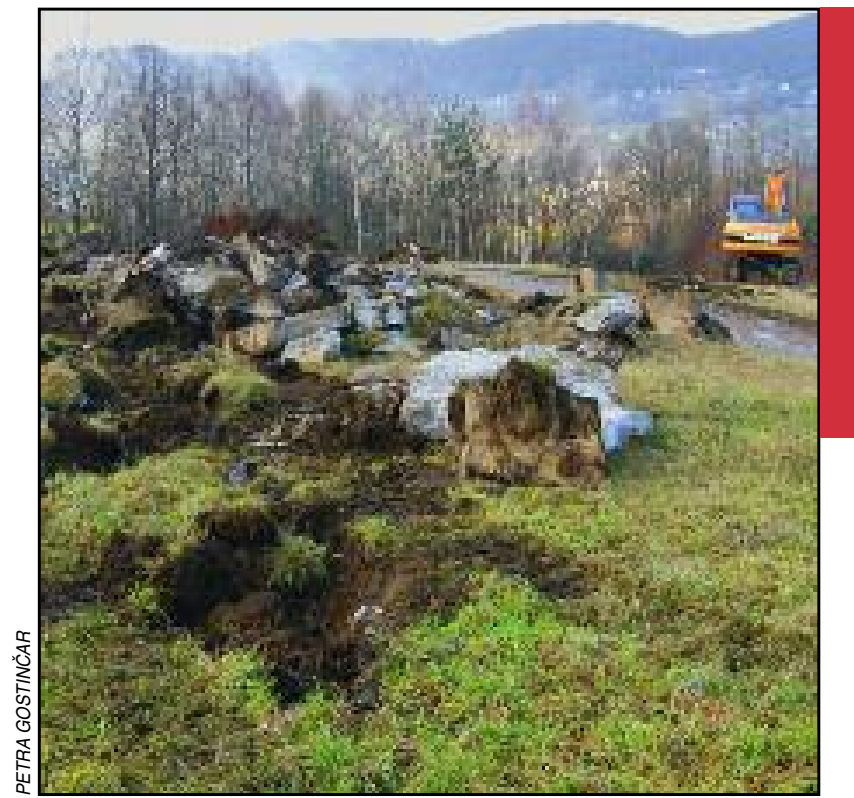

Mechanical clearing of rocks in karst areas. Strojno trebljenje kamna na krasu. 


\title{
Karst as a criterion for defining areas less suitable for agriculture
}

\author{
DOI: $10.3986 / A G S 52103$ \\ UDC: 91:631.111.2(497.4) \\ 631.111.2:551.435.8(497.4) \\ COBISS: 1.01
}

\begin{abstract}
The proposed European Union indicators for defining areas less suitable for agriculture in Slovenia are not entirely appropriate because taking them into account would omit some distinctly and clearly unsuitable areas - for example, Suha krajina (Dry Carniola) and Bela krajina (White Carniola) and farmers would be unjustifiably financially harmed. In such a case, every European Union member state has the right to propose an additional indicator to reduce such discrepancies. With regard to actual natural conditions, in Slovenia especially some karst landscapes would be unjustifiably omitted, and so we have proposed a karst indicator as an additional criterion based on the distribution of karst (i.e., carbonate) rocks. Through spatial coverage of karst rocks and soils, we determined whether more reasonable and less strict application of European criteria regarding soil could be satisfactory for better results in defining areas less suitable for agriculture in Slovenia.
\end{abstract}

KEY WORDS: Slovenia, European Union, landscape, karst, agriculture, criteria, less-suitable areas, less favourable areas, areas with limiting factors

The article was submitted for publication on May 18, 2012.

\section{ADDRESSES:}

\section{Rok Ciglič}

Anton Melik Geographical Institute

Research Center of the Slovenian Academy of Arts and Sciences

Gosposka ulica 13, SI - 1000 Ljubljana, Slovenia

E-mail: rok.ciglic@zrc-sazu.si

\section{Mauro Hrvatin}

Anton Melik Geographical Institute

Research Center of the Slovenian Academy of Arts and Sciences

Gosposka ulica 13, SI - 1000 Ljubljana, Slovenia

E-mail:mauro@zrc-sazu.si

Blaž Komac, Ph. D.

Anton Melik Geographical Institute

Research Center of the Slovenian Academy of Arts and Sciences

Gosposka ulica 13, SI - 1000 Ljubljana, Slovenia

E-mail: blaz.komac@zrc-sazu.si

\section{Drago Perko, Ph. D.}

Anton Melik Geographical Institute

Research Center of the Slovenian Academy of Arts and Sciences

Gosposka ulica 13, SI - 1000 Ljubljana, Slovenia

E-mail: drago@zrc-sazu.si 


\section{Contents}

1 Introduction 64

2 Karst 65

3 Methodology 72

$4 \quad$ Results for all land $\quad 77$

$5 \quad$ Results for agricultural land $\quad 78$

6 Conclusion 79

7 Acknowledgement 81

8 References 81 


\section{Introduction}

In 1999 the European Union defined three landscape types as areas with natural limitations for agriculture (Council regulation ... 1999, Articles 17, 18, 19, and 20; Review ... 2009):

- Mountain areas with a short growing season, steep slopes, and high elevation (encompassing $72.3 \%$ of Slovenia);

- Areas affected by specific handicaps, which are threatened due to special circumstances and where agriculture is necessary in order to protect the environment, preserve the cultural landscape, especially coasts, and for tourism purposes (10.0\% of Slovenia);

- Other less-suitable areas with long-term unfertile soil (4.0\% of Slovenia).

This means that $86.3 \%$ of Slovenia's area is classified as areas with natural limitations for agriculture (Report ...2010).

In 2005 the European Union defined 91 million ha or $57 \%$ of agricultural land as less suitable for farming. Although approximately 1.4 million people work this land, or only $13 \%$ of farmers, the European Union allocates significant funding to these areas. Between 2007 and 2013 the European Agricultural Guidance and Guarantee Fund (EAGGF) allocated $€ 12.6$ billion to these areas, which is $13.9 \%$ of funds earmarked for developing rural areas in the European Union. In 2004 payments for agriculture in less-suitable areas ranged between $€ 15$ and $€ 50$ per hectare in Spain, Estonia, Lithuania, Sweden, and Poland, and between $€ 170$ and $€ 250$ per hectare in Austria, Belgium, Finland, and Malta. The average payment for agriculture in less-suitable areas in the European Union was $€ 75$ per hectare (Eliasson et al. 2010).

For the majority of European areas with limiting factors for agriculture, it is typical that agriculture is unable to provide a sufficient income, that there are too few jobs in non-agricultural industries, and that the areas have poor connections to administrative centers. The consequences are seen in the abandonment of poor-quality land, overgrowth with grass and afforestation, and infrastructure decay. Along with worsening economic conditions, social conditions also deteriorate: there are fewer jobs, people move away, and service activities disappear (Cunder 2001). The same is true for Slovenia.

Recently the European Union placed greater emphasis on areas with poor climate conditions and low soil fertility (LFA ... 2012). For placing these areas in various categories of limitations after 2013, the EU proposed eight common biophysical criteria intended to apply only to Other less-suitable areas (Council regulation ... 1999, Article 19). The proposed criteria are (Commission ... 2012; Van Orshoven, Terres, \& Eliasson 2008; Elliason et al. 2010; Van Orshoven, Terres, \& Toth 2012):

- Low temperature

- Heat stress

- Soil drainage

- Soil texture and stoniness

- Soil rooting depth

- Chemical properties

- Soil moisture balance

- Slope

The criteria are combined into three groups: soil, climate, and terrain.

In Slovenia, vector data are available that make it possible to define agriculturally less-suitable areas and to calculate the effects of various biophysical criteria for the entire territory of the country. Suitable data layers are also available for the entire European Union (European soil ... 2012), but only a few countries have enough precise information available on soil, terrain, and climate (Pásztor, Szabó, \& Bakacsi 2010), which is especially true for Bulgaria and Romania (Elliason et al. 2010). Because of such a lack of uniformity, some countries oppose the introduction of common criteria for the entire European Union (Towers \& Birnie 2009).

By many geographical indicators, Slovenia falls among the countries with poor natural conditions for agriculture. This is already shown by data for certain terrain indicators, with which nearly all other natural factors are connected. A full $91.3 \%$ of Slovenia is over $200 \mathrm{~m}$ above sea level, and $34.9 \%$ is over $600 \mathrm{~m}$ above sea level. A full $83.7 \%$ of Slovenia's area has a slope of over $2^{\circ}, 70.5 \%$ over $6^{\circ}$, and $50.7 \%$ over $12^{\circ}$ (Perko 2007). Plains cover only $15.3 \%$ of Slovenia's area (Perko 2001), and even these are threatened by floods (regular flooding in one-tenth of plains, and catastrophic flooding in as much as one-third; Komac, 
Natek, \& Zorn 2008), and so only just under one-fourth of all agricultural land in Slovenia is located there (Cunder 2001).

Nonetheless, with regard to the eight European criteria cited above for determining areas less suitable for agriculture, a significant share of the area and agricultural land in Slovenia where natural conditions are clearly a limiting factor is unjustifiably omitted. This is most evident for some karst areas; for example, for Suha krajina (Dry Carniola).

Because European Union member states may, as an exception, also propose additional criteria or indicators, at the ZRC SAZU Anton Melik Geographical Institute we have designed a new, additional indicator based on the characteristics of karst terrain, which eliminates some of the shortcomings of the European indicators, which have become evident in Slovenia's above-average diversity of landscapes. We have thereby also substituted for the lack of certain data in Slovenia for individual European indicators. On the basis of this indicator, some areas in Slovenia that would otherwise unjustifiably be omitted according to the proposed European criteria are also categorized among areas less suitable for agriculture.

We have named this indicator or criterion karst or karstification, and it is categorized among terrain indicators.

\section{Karst}

The karstification of Slovenian landscapes is an explicit limiting factor for agriculture that geographers have already emphasized (Gams, Lovrenčak, \& Ingolič 1971; Gams 1974; Kladnik \& Senegačnik 1983; Gams 1987a, 1991; Kladnik 1998a; Cunder 2001). In their definition of karst landscapes, Kladnik and Senegačnik (1983) took into account the special elements of karst landscapes such as a bare surface, variable soil depth, rugged microterrain, dolines (sinkholes), flooding of karst poljes, and so on.

Outwardly, karstification is manifested in a special type of geomorphology that was primarily created through corrosion or the chemical dissolution of carbonate rock, primarily limestone and dolomite.

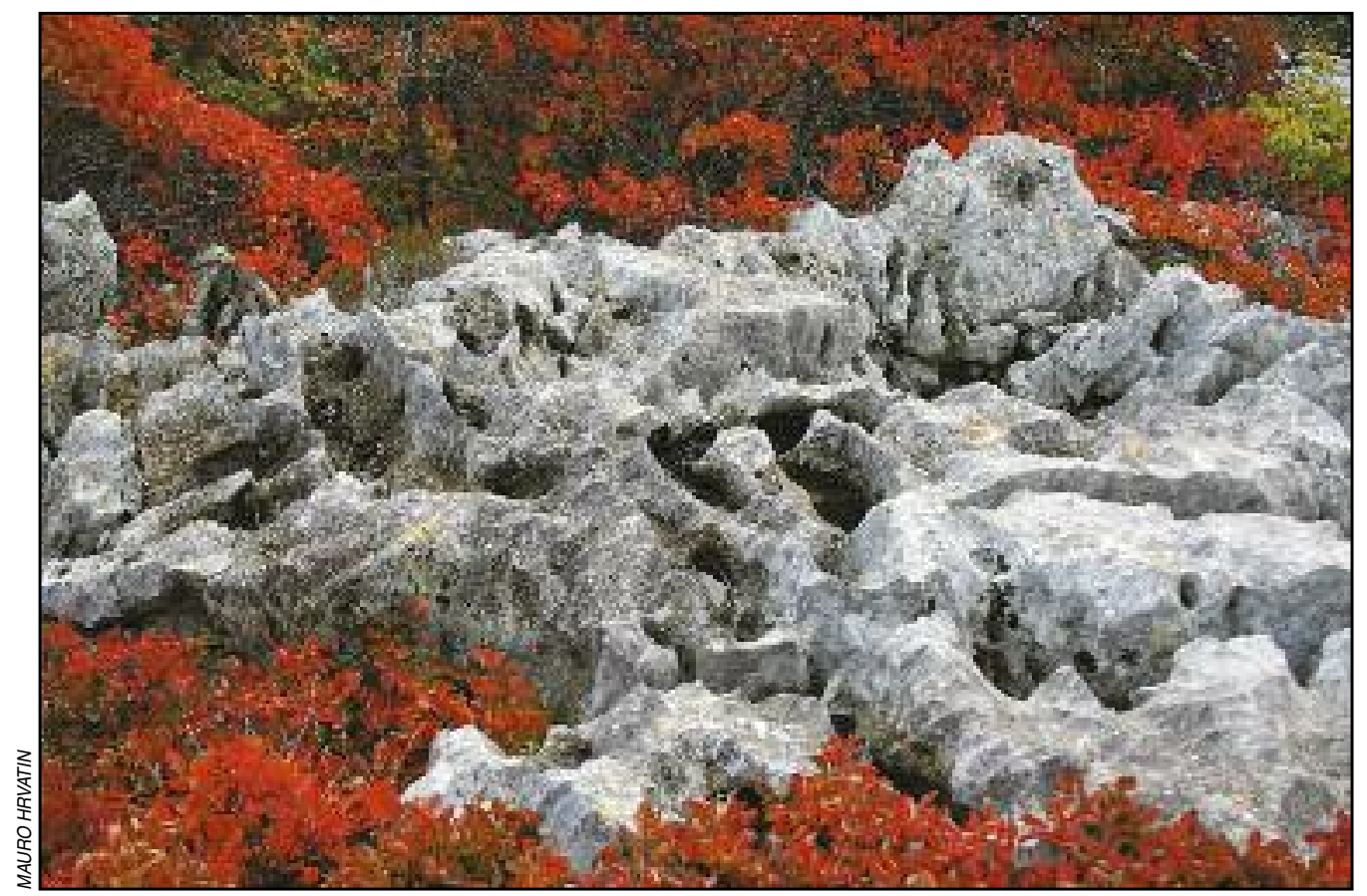

Figure 1: In common parlance, the Slovenian expression kras 'karst' refers to a bare, stony landscape. 


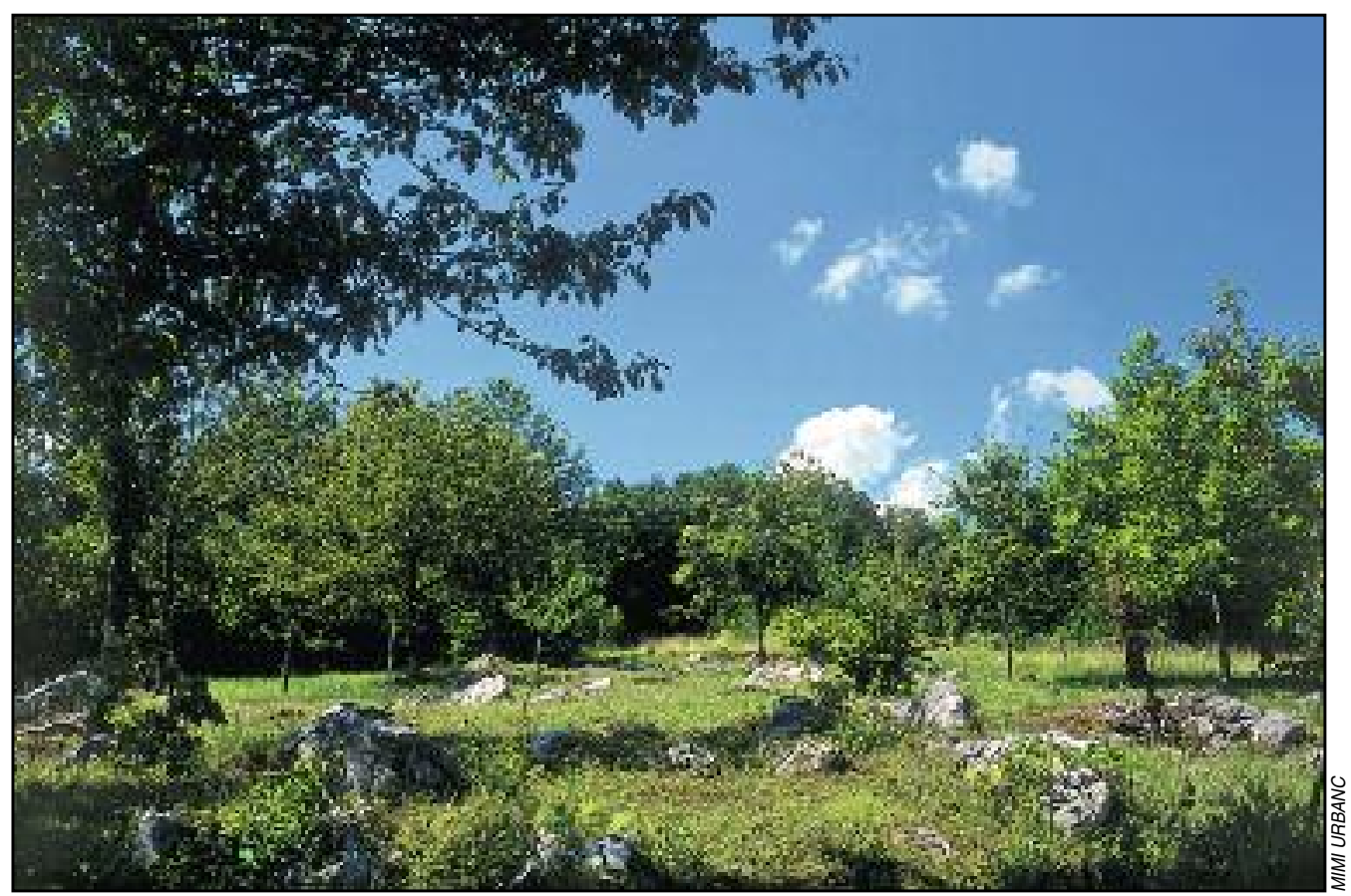

Figure 2: Stony land near Sela pri Hinjah in Dry Carniola.

For karst landscapes, there is a typical stony surface with dolines, collapse dolines, solution valleys, karst poljes, karst corrosion plains, and dry and blind valleys. In common parlance, the Slovenian expression kras 'karst' refers to bare, stony land. Karst is most often found on limestone or in areas where limestone alternates with other carbonate rocks, and is less common on other carbonate rocks or where carbonate rock alternates with non-carbonate rocks (Gams 1974; 2003).

Limiting factors due to karstification are:

- Terrain features: fine terrain dissection, primarily with dolines and similar corrosion features;

- Water conditions: a lack of surface water due to rapid drainage of water through porous karst rock, resulting in frequent droughts and greater fire danger;

- Soil: discontinuous, rocky, shallow, loamy, of uneven depth and with frequent protruding rocky outcrops and rare deeper pockets;

- Great karst dispersion of small plots of agricultural land, which impedes mechanical cultivation and the adaption of the land-use structure to modern agricultural methods.

The most characteristic and most numerous depression terrain feature in karst areas is the doline, a funnel-shaped corrosion depression measuring up to $50 \mathrm{~m}$ across and up to $10 \mathrm{~m}$ deep, with a floor covered with a thick layer of karst clay that is often the non-soluble remnant of chemical dissolution of carbonate rock. In addition to these, there are some large solution valleys and karst poljes. In many places there are extensive floods in karst poljes; for example, the Cerknica Polje may flood to cover an area of $27 \mathrm{~km}^{2}$ (Kranjc 1986). These are additional limiting factors for agriculture because the flooding may last several months. Among the first water-management plans in a Slovenian karst area in the eighteenth and nineteenth century was work to reduce and eliminate flooding in karst poljes, but for the most part these projects were not carried out or completed (Gams 1974).

Because of the predominance of subterranean water drainage, surface river networks in karst territory are very rare. On limestone karst there is more or less no surface water, and so in many places there is a great lack of water and droughts are frequent. Precipitation mostly drains through cracks directly underground, where it creates karst caves. The reshaping of karst rock is a result of their fissuring, permeability, and solubility. Precipitation absorbs carbon dioxide from the soil, which creates a weak carbonic acid. 


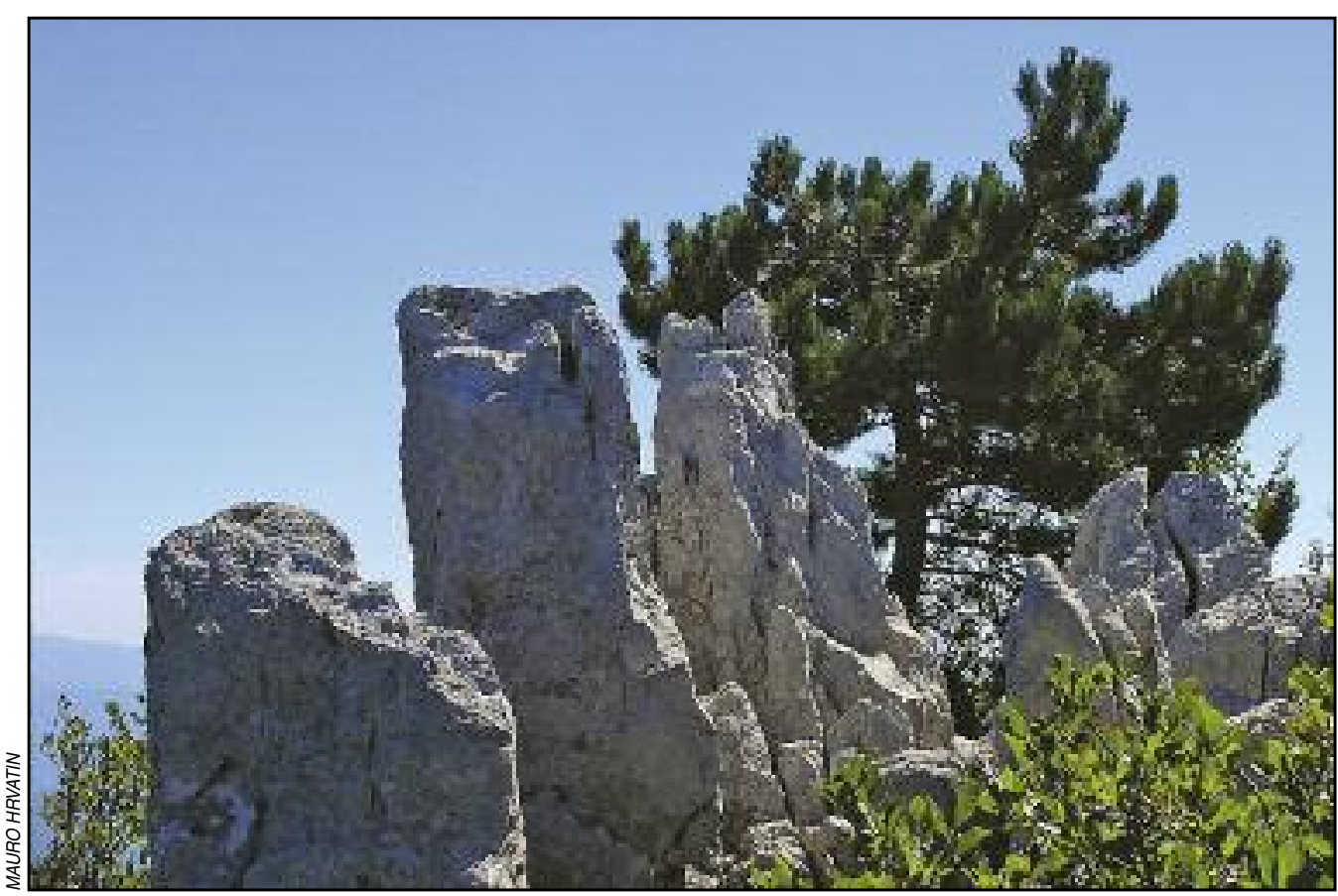

Figure 3: High rock horsts near Predmeja on the Trnovski gozd plateau.

This makes possible dissolution or corrosion already on the surface, and also below ground to some extent. Because of this, the karst surface slowly dissolves and decreases in elevation, on average by a few millimeters per century (Mihevc 1998, 2001, 2007).

With regard to the predominantly carbonate rock, a distinction is made between limestone and dolomite karst. Limestone is characterized by a semi-bare surface with intermingled rocky and soil-covered areas. The surface is comprised of rounded mountain tops and karst depressions. In some places there are more than 100 dolines per $\mathrm{km}^{2}$, and fewer on less pure limestone. In the Karst region, for example, the area between Lipica and Sežana stands out, with a density of as many as 150 dolines per $\mathrm{km}^{2}$, and near Markovščina in the karst Podgrad Lowland there are even $240 \mathrm{per} \mathrm{km}^{2}$. Dolines are more common in fissured, tectonically fractured areas (Natek et al. 1983; Šušterič 1984; Fridl et al. 1996; Gams 2000; Čar 2001)

The surface on limestone is often greatly karstified and so it is also difficult to cultivate in somewhat more level areas. The smallest karst features are rills, small parallel solution runnels carved out by precipitation on bare rock in the direction of the greatest flow. In a similar manner, karrens also form along the cracks and less resistant parts of the rock. In places the rock is so strongly karstified that many rocky horsts protrude from the surface, and rocky talus-covered areas are frequent on slopes and ridges (Gams 2003).

Limestone rock exposed to chemical dissolution on the surface has a finely divided and rough surface, whereas limestone rock lying in the soil has a smooth or rounded surface. Because of this, everywhere that erosion has removed soil due to human activity it is possible to determine the level to which the soil cover once extended (Gams 1971). In this manner one can also draw conclusions about the intensity of soil erosion, which is often an overlooked geomorphic process in karst areas because water continues to leach the soil under the surface. There is often insufficient awareness of the intensity of leaching soil below the surface. Especially intense surface leaching of soil takes place on steep slopes during downpours, and so abandoned vineyards often turn into real rocky deserts (Hrvatin et al. 2006).

Soil erosion in karst areas is determined indirectly. In flat karst meadows the rock usually protrudes 20 to $30 \mathrm{~cm}$ from the earth and that is also the extent of the effect of erosion. In vineyards, erosion is usually much greater. Soil erosion in karst areas presumably varied during different historical periods. After forests were cleared and the soil was first tilled, it was more rapid, but then it gradually slowed down. In 


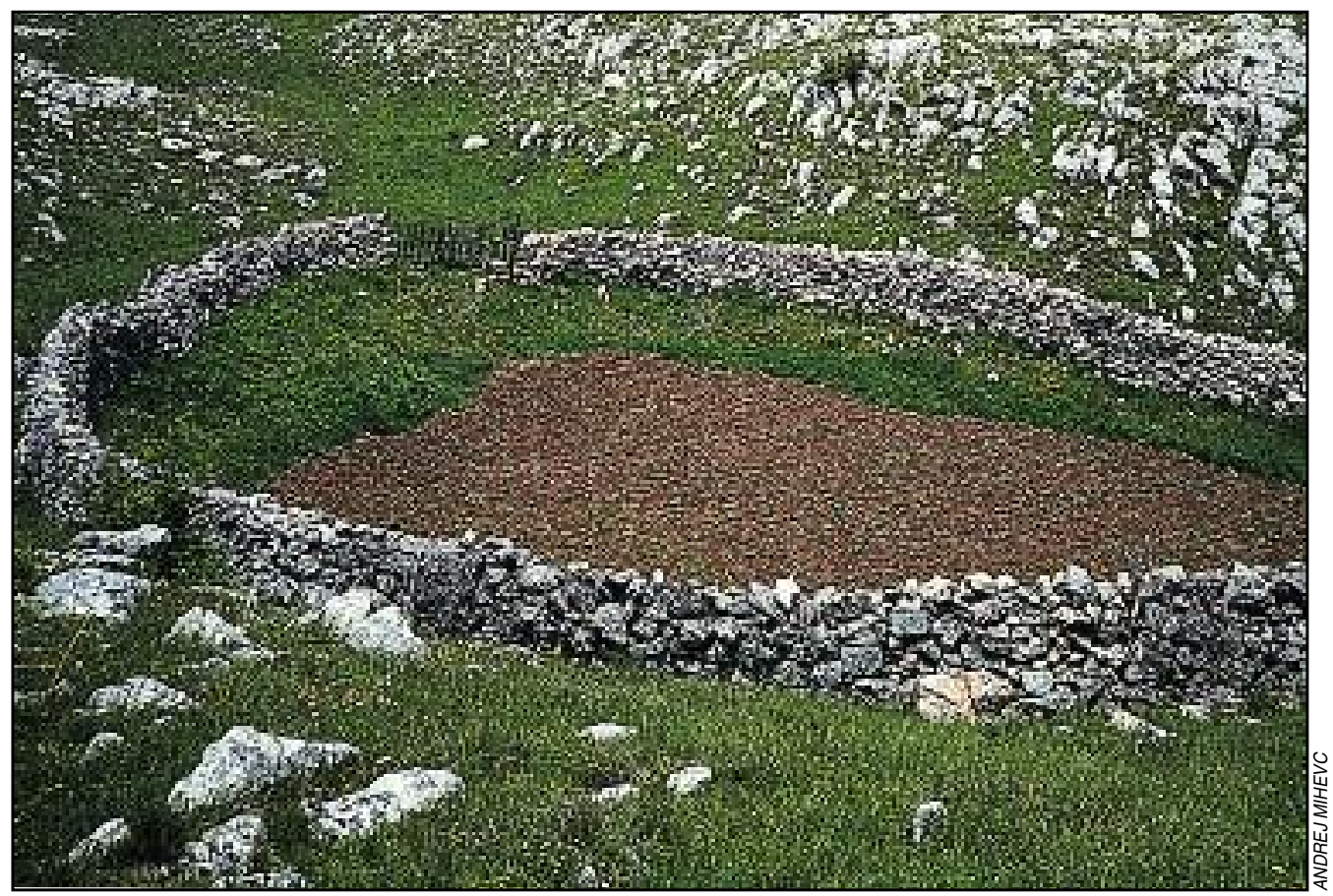

Figure 4: A typical cultivated doline.

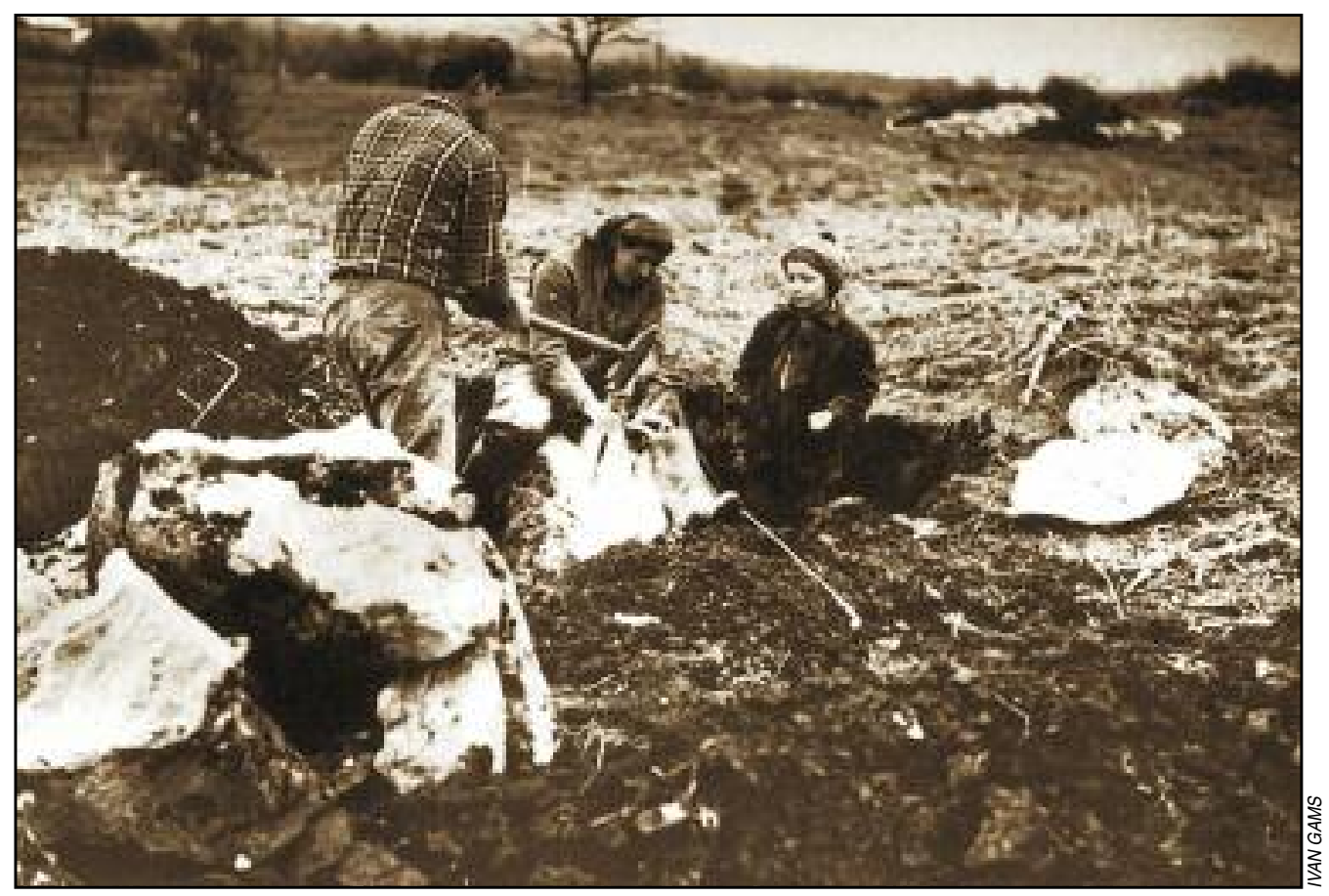

Figure 5: Former hand clearing of rock near Suhor in White Carniola. 


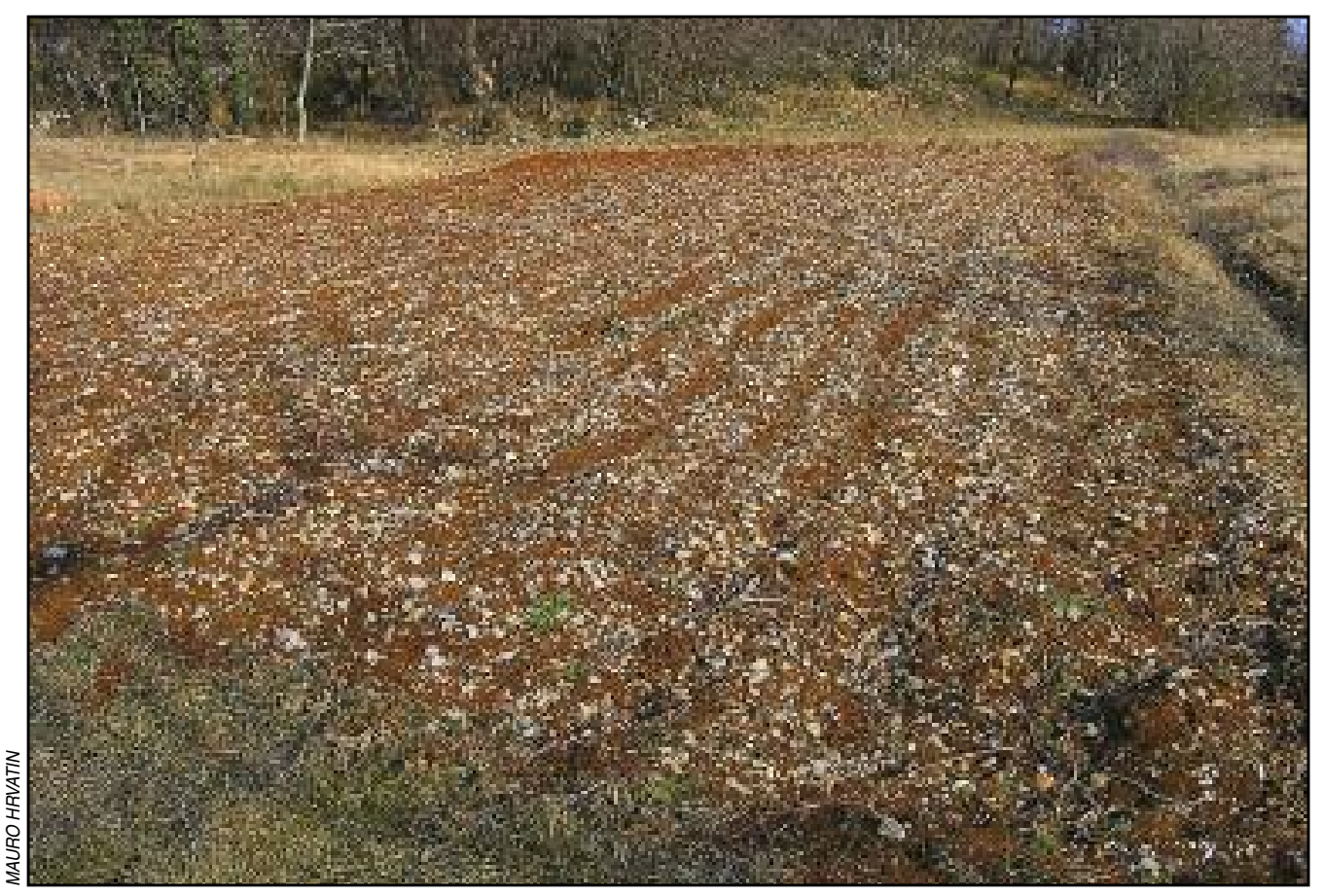

Figure 6: Very stony soil in a tilled field near Lokvica in the Karst region.

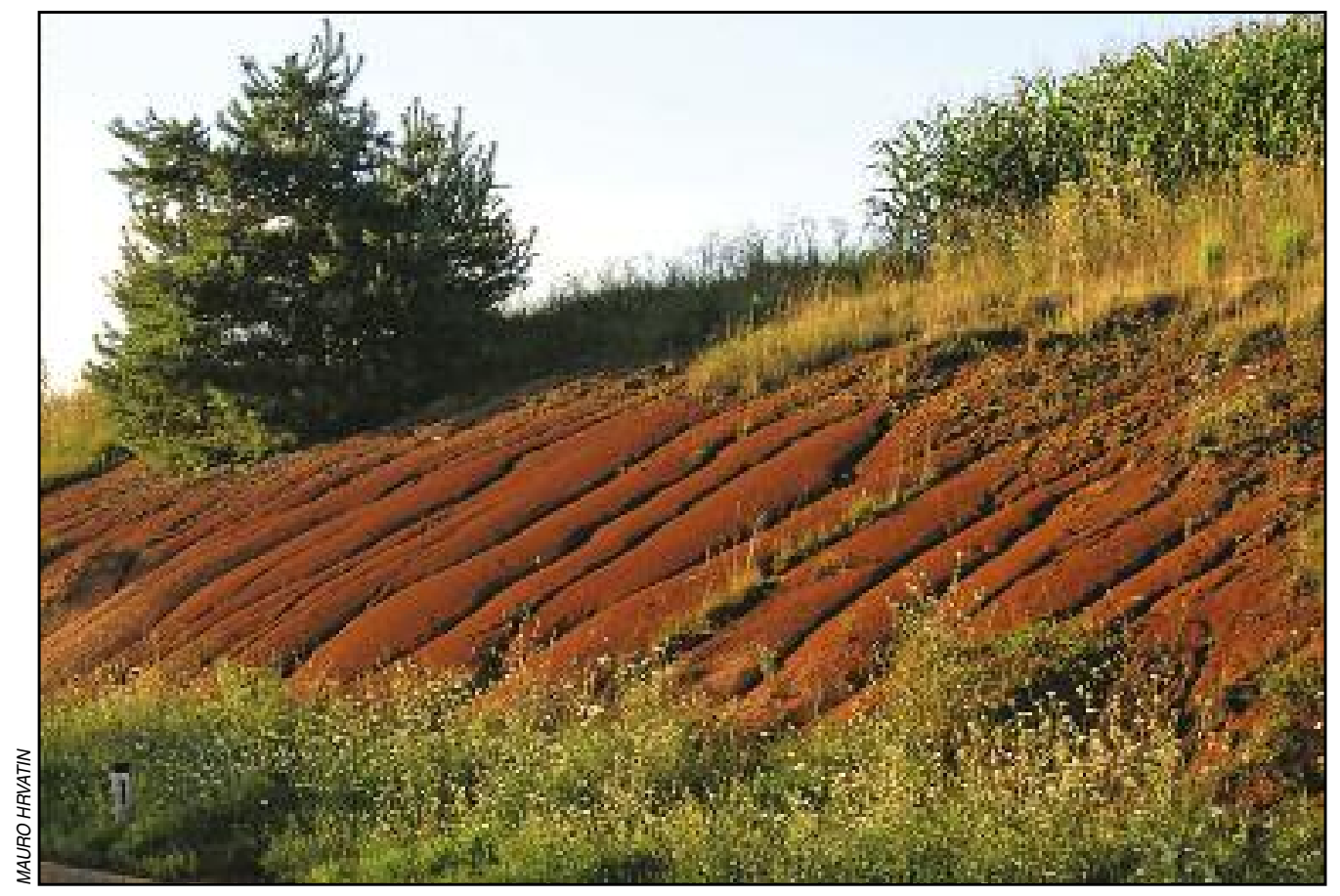

Figure 7: Thick red loamy clays at Cikava in the Grosuplje Basin. 


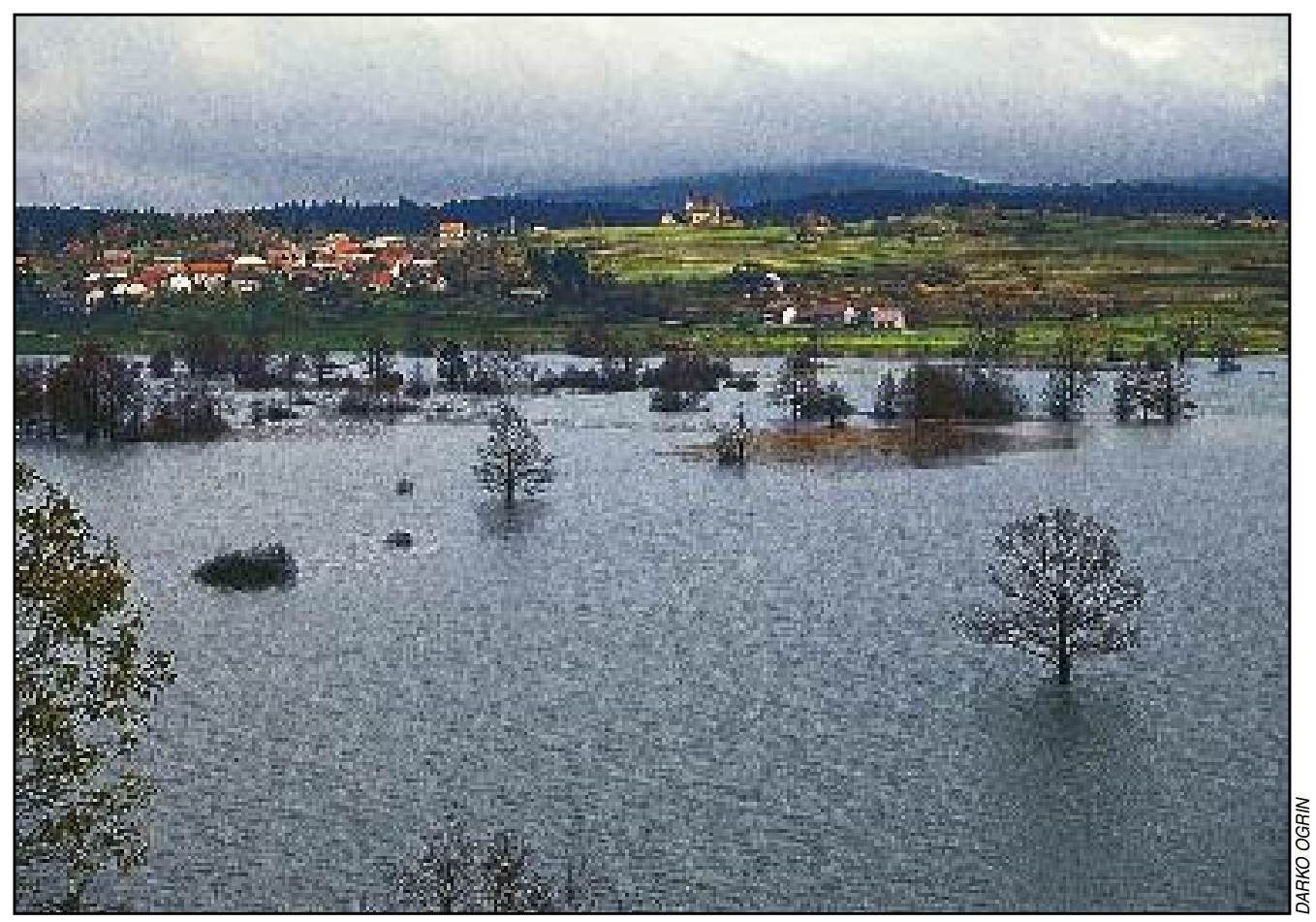

Figure 8: Annual flooding in the Planina Polje.

tilled fields and vineyards in southeast Slovenia it has been determined that the soil thickness is diminishing on average by $1 \mathrm{~cm}$ per year (Hrovat 1953), and on average in Slovenia 3 to 5 tons of soil per hectare of tilled land are lost annually (Komac \& Zorn 2005).

On dolomite karst, typical karst terrain features are less common and so such karst is usually less distinct than limestone karst. Shallow dry valleys, or hollows, are typical. In addition to the chemical dissolution of rock, erosion and denudation are also important on dolomite, and so in many places dolomite karst resembles fluvial denudation terrain and is also referred to as fluviokarst (Komac 2003).

The surface on carbonate rock is generally less suitable for agriculture. Because of its highly dissected and stony surface, cultivating the soil was always connected with great investments in land improvement. Sufficient soil depth for tilled fields is only found on the bottom of various types of karst basins, in dry and blind valleys, and on karstified plateaus. In the past people tried to improve the cultivation potential by clearing rock from the karst surface. If they wanted to be able to mow, the stone had to be removed down to the soil level, and if they wanted to till the land this removal extended into the soil: 20 to $30 \mathrm{~cm}$ for an iron plow, and $50 \mathrm{~cm}$ for trench plowing. The broken-off rock was deposited in shafts and collapse dolines or collected in rockpiles, or dry walls were built from it (Gams 1987b).

Among the most widespread improvement efforts in karst areas was doline cultivation, in which their shape was also changed, creating what are known as cultivated dolines. Major effort also resulted in cultivated meadows and tilled terraces with retaining walls. The extent to which rock was removed from the karst surface can be estimated from the broken-off rock that was built into retaining walls and other walls, and in places also rockpiles. Such stone walls often surround cultivated dolines that contained small tilled fields. This also protected the crops from grazing animals. Often several hundred kilograms of stone were removed per square meter. In the Divača Karst region three-quarters of the rock built into walls shows signs of having been broken off (Gams 1991; Kladnik 1998b).

The bottoms of cultivated dolines, which have smooth slopes and a sharp, unnatural transition from the slope to the floor, were leveled with soil that was taken from the slopes and nearby area. Tilled fields 
Figure 9: White Carniola seems flat, but is actually a greatly karstified and highly dissected landscape.

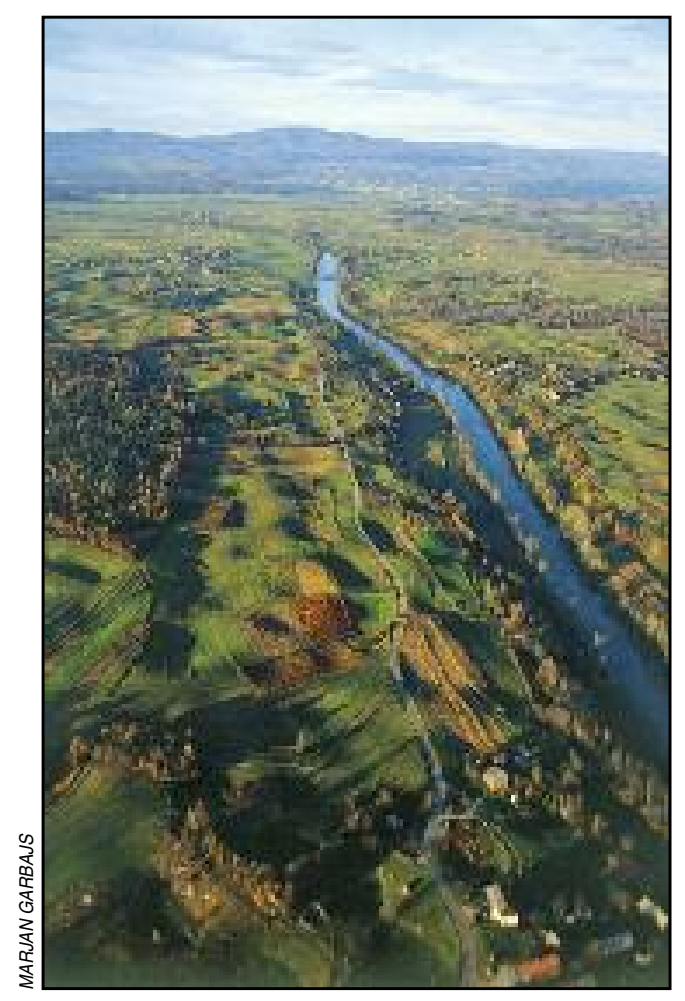

and meadows were preserved the longest in them. In the past there was a sharp division between grubbed-out meadows and pastures that had not been cleared of rocks, where the rock sometimes covered more than half of the pasture. Cultivated dolines were once an important part of the traditional cultivated landscape; now they are mostly abandoned or contain meadows or pastures. They were often surrounded by dry walls. The nineteenth-century cadastral map for the village of Lokev in the Karst region shows about 100 circular dry-walled enclosures that protected small tilled fields against animals, leaching by rain, and erosion by the bora wind. In the village of Krajna Vas over half of all of the dolines were cultivated (Gams 1987a).

The soil that covers the karst surface has an uneven depth and rock often protrudes from it. The uneven soil depth is the greatest limiting factor for cultivating karst land. Rendzina and chromic cambisol soils predominate on karst; these are often highly leached and contain few carbonates. On limestone with chert more acidic and sandy soil has developed, locally referred to as kremenica 'cherty terra rossa', and on more pure limestone ilovka 'loamy terra rossa'. In the central horizon of cherty terra rossa, pedological studies have determined 56 to $75 \%$ acidic $\mathrm{SiO}_{2}$, and in loamy terra rossa only 49 to $57 \%$. The share of clay particles in the same horizon is approximately the same: 56 to $75 \%$ in cherty terra rossa and 49 to $75 \%$ in loamy terra rossa. A favorable quality of karst terra rossa is the large volume of colloidal particles, because of which it is able to retain large quantities of water. This quality is significantly reduced by larger stony particles, which appear in cultivated karst soils to a large degree due to breaking off rock during land improvement (Hrovat 1953; Gams 1974).

When farmers cleared the forest on the semi-bare karst, the cleared land was only useful for grazing. Today there is little awareness that the farmers had to pull the karst rock out for the majority of areas used for tilled fields and meadows. The extent to which rock was grubbed out of the karst land can be estimated from the amount of broken-off stone found in retaining walls and other walls.

Until the Second World War, rocks were mostly removed by hand, and up to $200 \mathrm{~kg}$ of stone were removed per square meter of land. The extent of such land improvement was small and was largely limited to the land in the immediate vicinity of people's residences (Gams, Lovrenčak, \& Ingolič 1971). 
After the Second World War, stones started being grubbed out mechanically using excavators and bulldozers (Hrvatin 1985). Mechanical land improvement is a time-consuming and labor-intensive process that generally includes the following phases:

- Clearing forest

- Leveling the surface with heavy bulldozers

- Removing smaller rock by hand

- Mechanical digging and transport of soil

- Mechanical leveling of soil

For example, in the Trebnje region of Dry Carniola the clearing of 2,100 ha of land by 1990 involved the removal of $41,000 \mathrm{~m}^{3}$ of stone, or $19.7 \mathrm{~m}^{3}$ or five tons per hectare. When rock is broken up mechanically, many stone fragments remain in the soil, which reduces the soil's water-retention capacity and contributes to soil aridity (Gams 2003).

Because carbonate rocks are water permeable, agricultural land is often affected by drought during the growing season. The lack of a network of surface water prevents any kind of irrigation. Soil aridity is further increased by the stone debris, which is often mixed with the soil due to grubbing. Fires are also more frequent on karst land because of drought (Ogrin 2002).

The literature also includes descriptions of natural conditions less suitable for agriculture on karst in other countries. He et al. (1998) cited many obstacles faced by agriculture in the Chinese province of Guizhou. Among these, they highlighted low soil alkalinity, poor fertility, slow soil formation, shallow soil, and substantial soil erosion, which is the greatest in irrigated areas but is also increased by excessive clearing of forested land. They also highlighted accessibility to water resources, which are very threatened due to subterranean drainage and therefore »water becomes as expensive as oil.«In the case of this Chinese province it is also characteristic that the share of agricultural land is small (between 5 and 10\%). Ulrich (1989) observed that planning in tropical karst areas differs from planning in other tropical areas and demands special measures. He highlighted groundwater maintenance, storage of surface water, unsupervised waste dumping, and the general vulnerability of the ecosystem. Because of their mountains and/or karst surface, countries in the western Balkans also have poorer conditions for agriculture (Volk, Rednak, \& Erjavec 2010).

\section{Methodology}

In order to define the karst indicator, define areas less suitable for agriculture with regard to the karst indicator, and to determine the connection between karst rocks and soils, we first defined karst lithographic and pedological units.

A high degree of correlation between karst rocks, on which the karst indicator is based, and karst soils, which satisfy the conditions for the soil criteria, would mean that the (omitted) agricultural land in question could be categorized among areas less suitable for agriculture simply by applying appropriate lithological units, and therefore the introduction of a new criterion - that is, a karst indicator - would not be necessary. Specifically, for each individual pedological unit it is possible to determine whether it generally (on average) satisfies the conditions of at least one of the criteria from the soil group (permeability, texture and stoniness, soil rooting depth, chemical properties, and soil moisture balance) for classification as an area less suitable for agriculture. The indicator for soil rooting depth, for example, has a borderline value of $30 \mathrm{~cm}$, which means that all types of soil or pedological units in which soil rooting depth usually does not exceed $30 \mathrm{~cm}$ satisfy the measure for classification as an area less suitable for agriculture. Such borderline criteria are also, for example, that clay particles must exceed $60 \%$ or that rock outcrops must extend more than $15 \mathrm{~cm}$ above the soil.

A vector data layer with karst rocks (Zemljevid tipov kamnin ... 2012) was prepared based on the vector layer of the 1:250,000 Lithological Map (Litoloska karta), which we produced based on the Lithostratigraphic Map of Slovenia (Litostratigrafska karta... 2007; 2011 revision), which in turn was prepared for the 


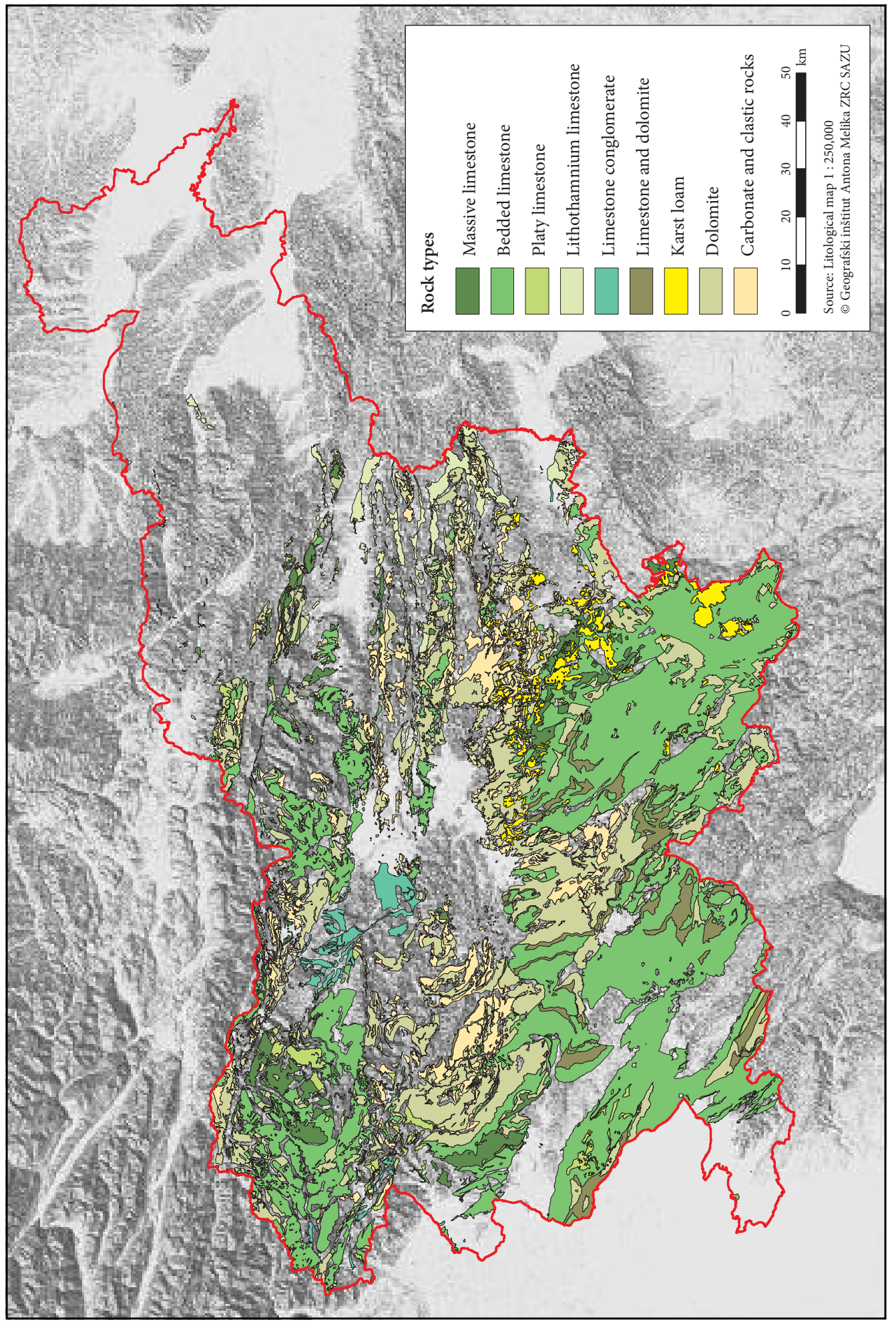


Rok Ciglič, Mauro Hrvatin, Blaž Komac, Drago Perko, Karst as a criterion for defining areas less suitable for agriculture

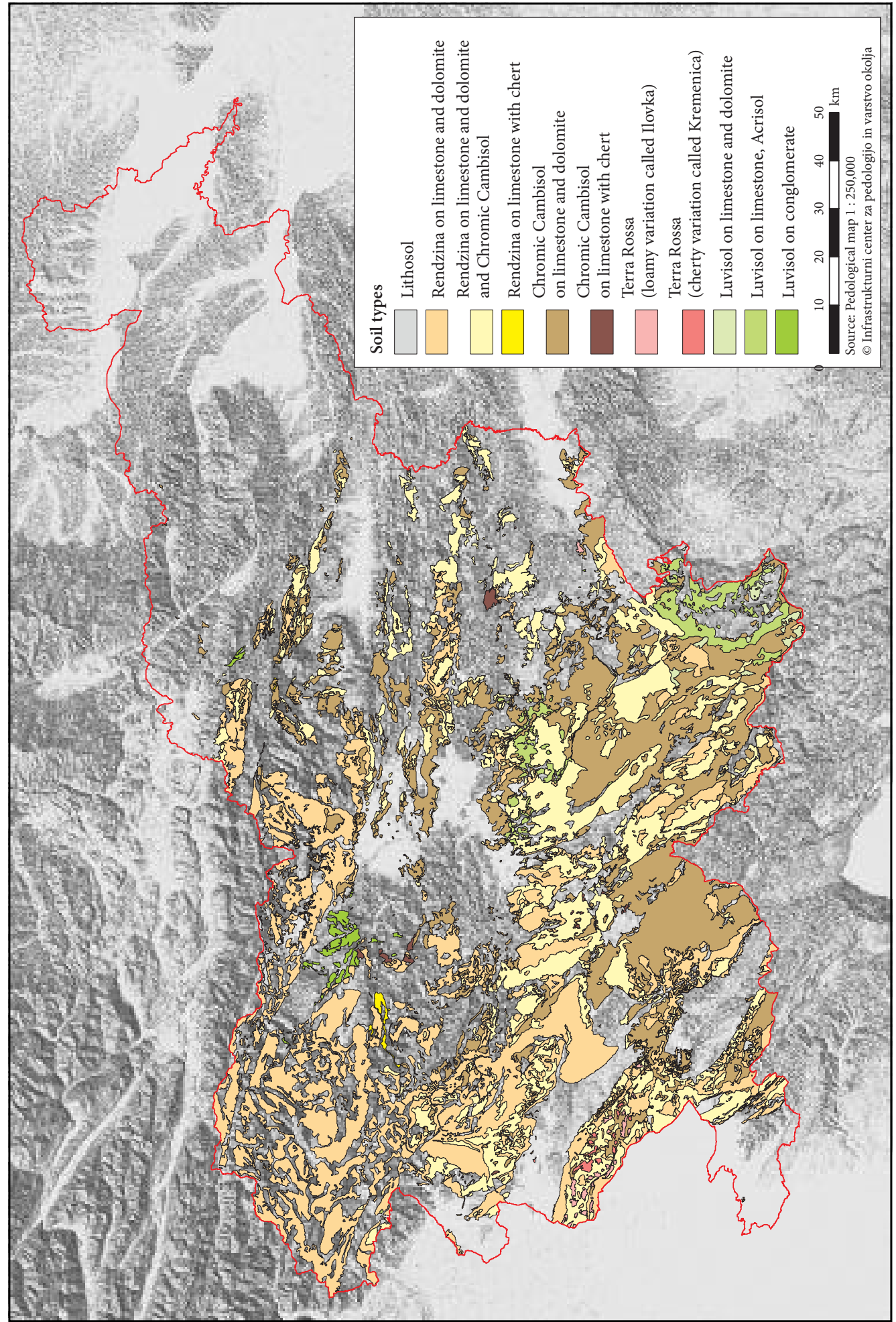


Acta geographica Slovenica, 52-1, 2012

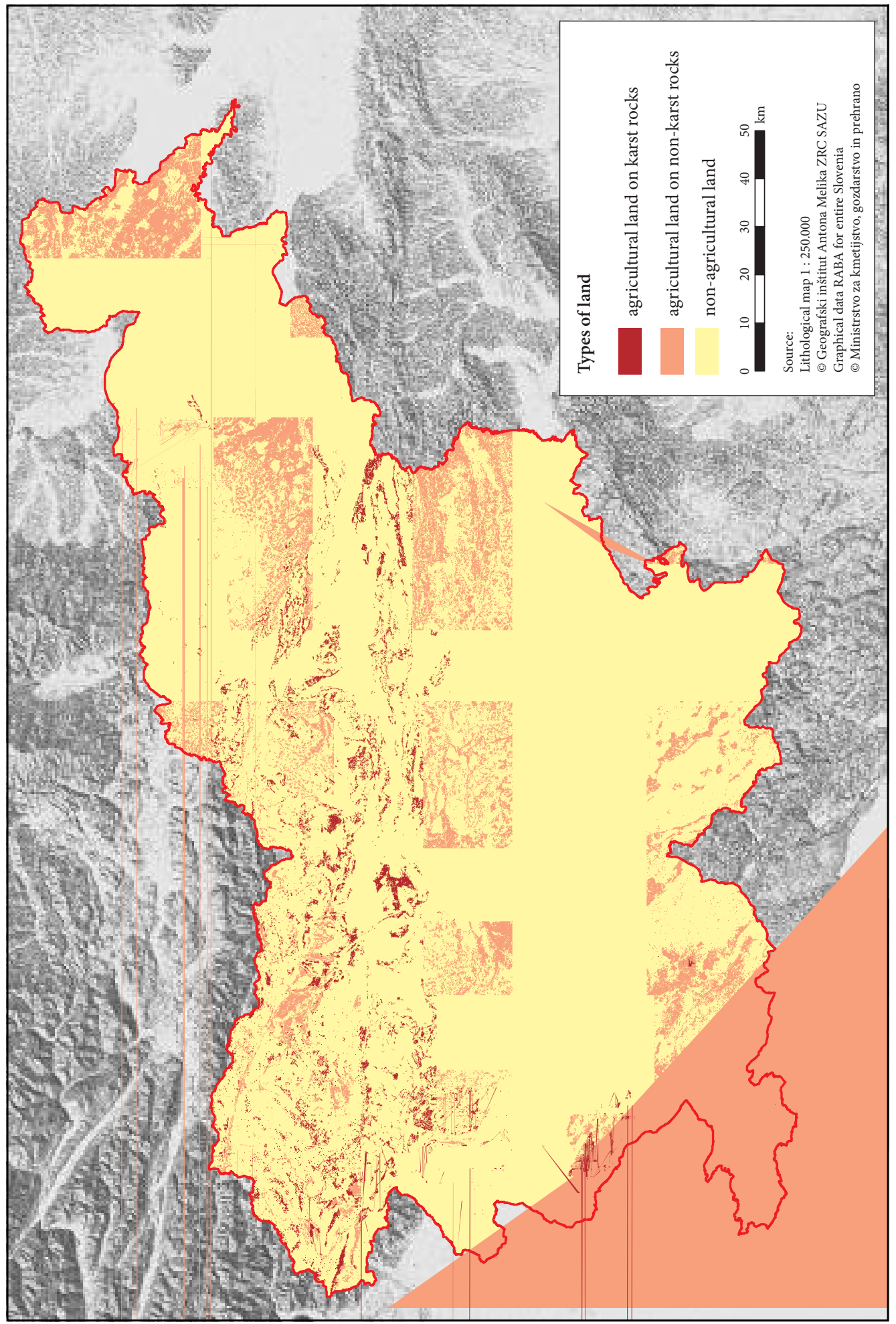


Rok Ciglič, Mauro Hrvatin, Blaž Komac, Drago Perko, Karst as a criterion for defining areas less suitable for agriculture

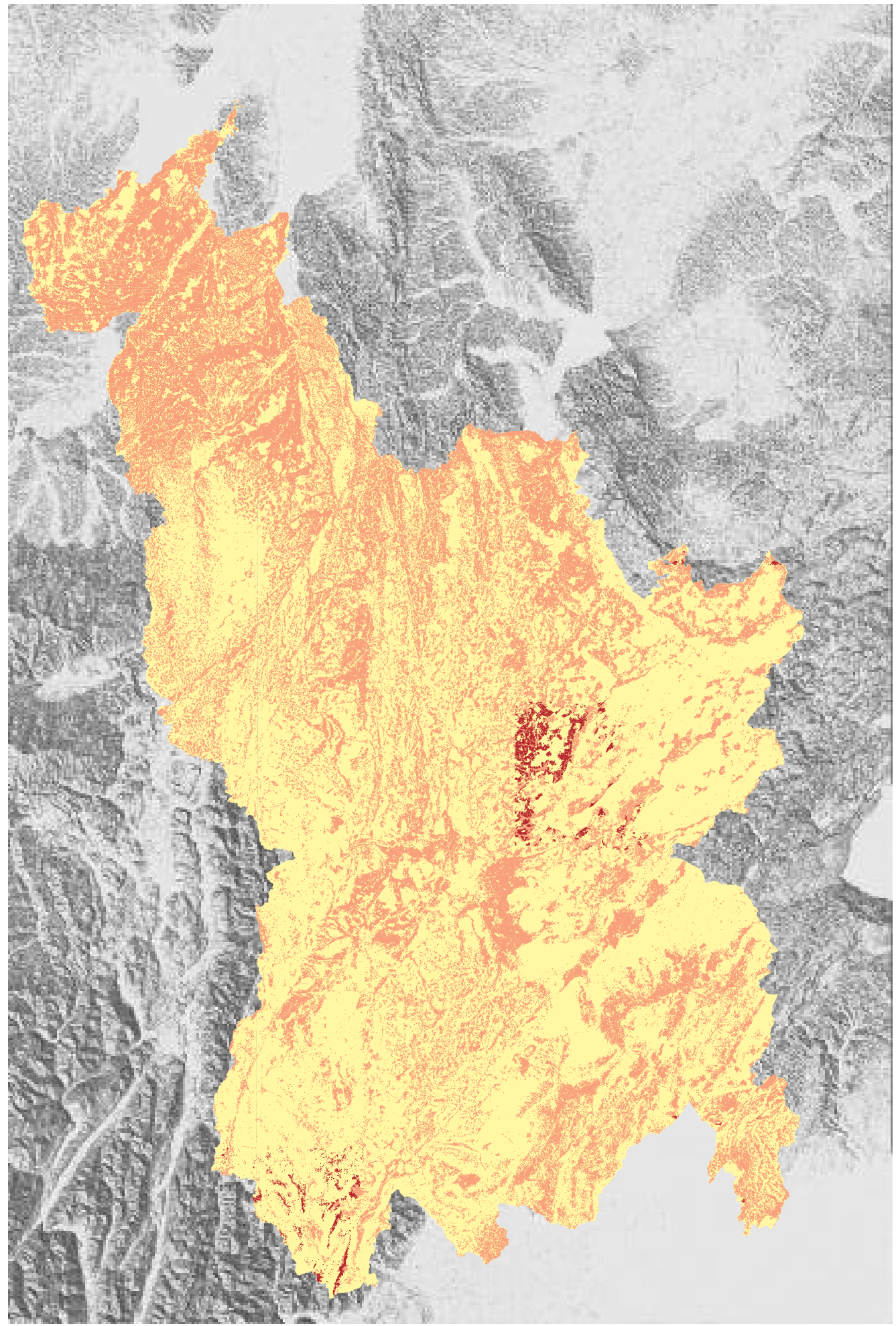


Environmental Agency of the Republic of Slovenia primarily based on 1:25,000 vectorized geological maps of Slovenia produced by the Geological Survey of Slovenia.

Karst rock types comprise the following lithographic units:

- Massive limestone

- Bedded limestone

- Platy limestone

- Lithothamnium limestone

- Limestone conglomerate

- Limestone and dolomite

- Karst loam

- Dolomite

- Carbonate and clastic rocks

We prepared a vector data layer with karst soils based on the vector layer of the $1: 250,000$ Pedological Map (Pedološka karta), which was produced by the Infrastructure Center for Soil Science and Environmental Protection (TIS/ICPVO - Infrastrukturni center za pedologijo in varstvo okolja, Biotechnical Faculty, University of Ljubljana, Ljubljana 1999-2011). We selected those soils whose characteristics match the measures for all five general European biophysical criteria in the soil group:

Karst soil types comprise the following pedological units:

- Lithosol

- Rendzina on limestone and dolomite

- Rendzina on limestone and dolomite and chromic cambisol

- Rendzina on limestone with chert

- Chromic cambisol on limestone and dolomite

- Chromic cambisol on limestone with chert

- Loamy terra rossa

- Cherty terra rossa

- Luvisol on limestone and dolomite,

- Luvisol on limestone, acrisol

- Luvisol on conglomerate

We have prepared a contingency table that shows how much karst soils there is on karst rocks and how much on non-karst rocks - or how much karst rocks is under karst soils and how much is under non-karst soils (Table 1).

Based on the frequency distribution, we first calculated the statistical indicator $h i^{2}$, and from this the statistical indicators $r^{2}$ (coefficient of determination) and $r$ (correlation coefficient), which show the level of correlation. In a similar manner we also prepared a contingency table only for agricultural land with karst rocks and soils (Table 2).

\section{Results for all land}

In Slovenia, which has an area of $20,273 \mathrm{~km}^{2}, 9,142 \mathrm{~km}^{2}(45.1 \%)$ of the surface has karst rocks and 7,975 km (39.3\%) has karst soils.

The distribution of karst rocks and karst soils alone shows that they are strongly correlated. From the contingency table (Table 1) it is clear that a full $91.8 \%$ of karst soils is on karst rocks, and that $85.2 \%$ of non-karst soils is on non-karst rocks. At the same time, $80.1 \%$ of karst rocks is below karst soils and a full $94.1 \%$ of non-karst rocks below non-karst soils.

Altogether, $36.1 \%$ of Slovenia is comprised of a combination of karst rocks and karst soils, and 51.7\% of Slovenia is a combination of non-karst rocks and non-karst soils, which totals $87.8 \%$. This means that, with regard to data used, a total of $12.2 \%$ of Slovenia is not one of these combinations or, in other words, barely one-tenth of the area of Slovenia is a combination of karst rocks and non-karst soils, or non-karst rocks and karst soils.

This high degree of correlation is also confirmed by the correlation coefficient $r$, which we calculated from $h i^{2}$ based on over 32 million $25 \mathrm{~m} \times 25 \mathrm{~m}$ square cells. The value of the correlation coefficient $r$ is 0.7555 . Both $h i^{2}$ and $r$ (Table 1) significantly exceed the threshold of their theoretical values at an error probability of 0.01 , and therefore it can be concluded with $1 \%$ uncertainty or $99 \%$ certainty that the spatial distribution of karst rocks and karst soils has a statistically significant correlation. 
Table 1: Contingency table with karst rocks and soils.

\begin{tabular}{lccc}
\hline Rocks and soils & $\begin{array}{c}\text { Non-karst rocks } \\
\text { ha }\end{array}$ & $\begin{array}{c}\text { Karst rocks } \\
\text { ha }\end{array}$ & $\begin{array}{c}\text { Total } \\
\text { ha }\end{array}$ \\
\hline Non-karst soils & $1,047,467$ & 182,290 & $1,229,757$ \\
Karst soils & 65,574 & 731,955 & 797,529 \\
Total & $1,113,041$ & 914,245 & $2,027,286$ \\
\hline & $\%$ & $\%$ & $\%$ \\
Non-karst soils & 85.2 & 14.8 & 100.0 \\
Karst soils & 8.2 & 91.8 & 100.0 \\
Total & 54.9 & 45.1 & 100.0 \\
\hline Non-karst soils & 94.1 & 19.9 & 60.7 \\
Karst soils & 5.9 & 80.1 & 39.3 \\
Total & 100.0 & 100.0 & 100.0 \\
\hline Non-karst soils & 51.7 & 9.0 & 60.7 \\
Karst soils & 3.2 & 36.1 & 39.3 \\
Total & 54.9 & 45.1 & 100.0 \\
\hline Statistical indicators & & & $18,513,792.64$ \\
$h^{2}$ & & & 0.5708 \\
$r^{2}$ & & & 0.7555 \\
$r$ & from $32,365,580$ cells &
\end{tabular}

\section{Results for agricultural land}

In the previous section we determined the spatial connection between karst rocks and soils for all land in Slovenia. This section only does so for agricultural land. In Slovenia there is $6,640 \mathrm{~km}^{2}$ of agricultural land (32.8\% of the country's territory), of which $1,927 \mathrm{~km}^{2}$ ( $29 \%$ of this land) is on karst rocks and $1,438 \mathrm{~km}^{2}$ $(21.7 \%)$ is on karst soils.

The very distribution of karst rocks and karst soils shows that they are strongly correlated. From the contingency table (Table 2) it is clear that a full $90.8 \%$ of karst soils is on karst rocks and that $88.1 \%$ of non-karst soils is on non-karst rocks. At the same time, $67.8 \%$ of karst rocks is under karst soils and a full

Table 2: Contingency table of agricultural land with karst rocks and soils.

\begin{tabular}{lccc}
\hline Rocks and soils & $\begin{array}{c}\text { Non-karst rocks } \\
\text { ha }\end{array}$ & $\begin{array}{c}\text { Karst rocks } \\
\text { ha }\end{array}$ & $\begin{array}{c}\text { Total } \\
\text { ha }\end{array}$ \\
\hline Non-karst soils & $458,045.19$ & $62,114.69$ & $520,159.88$ \\
Karst soils & $13,184.19$ & $130,611.81$ & $143,796.00$ \\
Total & $471,229.38$ & $192,726.50$ & $663,955.88$ \\
\hline & $\%$ & $\%$ & $\%$ \\
Non-karst soils & 88.1 & 11.9 & 100.0 \\
Karst soils & 9.2 & 90.8 & 100.0 \\
Total & 71.0 & 29.0 & 100.0 \\
\hline Non-karst soils & 97.2 & 32.2 & 78.3 \\
Karst soils & 2.8 & 67.8 & 21.7 \\
Total & 100.0 & 100.0 & 100.0 \\
\hline Non-karst soils & 69.0 & 9.4 & 78.3 \\
Karst soils & 2.0 & 19.7 & 21.7 \\
Total & 71.0 & 29.0 & 100.0 \\
\hline Statistical indicators & & & \\
hi $^{2}$ & from $32,365,580$ cells & & $5,445,170.517$ \\
$r^{2}$ & & & 0.5126 \\
\hline
\end{tabular}


$97.2 \%$ of non-karst rocks is under non-karst soils. These are therefore the proportions that apply to karst land on karst rocks and karst soils in Slovenia.

A high degree of correlation is also confirmed by the correlation coefficient $r$, which we calculated from $h i^{2}$ based on over 32 million $25 \mathrm{~m} \times 25 \mathrm{~m}$ square cells. The value of the correlation coefficient $r$ is 0.7159 . Both $h i^{2}$ and $r$ (Table 2) significantly exceed the threshold of their theoretical values at an error probability of 0.01 , and therefore it can be concluded with $1 \%$ uncertainty or $99 \%$ certainty that the spatial distribution of karst rocks and karst soils has a statistically significant correlation.

This means that the spatial distribution of karst rocks and soils has a statistically significant correlation overall, for all land (0.7555) as well as for only agricultural land (0.7159), or that there is no significant difference between the correlation coefficients.

\section{Conclusion}

For the comprehensive evaluation of agricultural land it is necessary to take into account the karst indicator because karst areas are characterized by special cultivation conditions. Despite the rather high level of precipitation in karst areas in Slovenia, the water permeability of karst rock and primarily subterranean water flow makes supplying water difficult. Because of the low concentration of insoluble components in the rock, soil is formed more slowly on limestone than on other types of rock, and erosion is also frequent in clear-cut karst areas. The surface on karst rock is therefore covered with relatively shallow soil and the share of stony material in it is exceptionally large. Since time immemorial, farmers have had to improve the soil (e.g., by grubbing out rock) in order to achieve better agricultural conditions in at least some places.

Agriculture is also encumbered by the great vulnerability of the karst ecosystem. Possible overuse of mineral fertilizers and pesticides can be very dangerous because in karst areas substances are leached directly under the ground, from where they end up in karst springs, which are the only sources of drinking water in karst regions.

It is understandable that taking into account these characteristics of karst rock is necessary in evaluating Slovenian agricultural land. The karst indicator that we have defined is based on the lithological composition of the surface and takes into account the areas of karst rock; that is, rock on which karst has formed. We used these areas to calculate the share of karst area in Slovenian cadastral districts and to determine a high degree of correlation between karst rocks and karst soils. This correlation justifies the possibility that an indicator could also be based on karst soil defined with the help of a pedological map.

The areas less suitable for agriculture should completely include cadastral districts in which at least two-thirds of agricultural land is located on karst rock. In Slovenia, among 2,697 cadastral districts, there are 561, or one-fifth (20.8\%), in which at least two-thirds of the agricultural land is in areas less suitable for farming based on the karst indicator. The total area of agricultural land in these 561 districts is 148,677 ha (of which 133,122 ha is on karst rock), which is $22.4 \%$ of all agricultural land in Slovenia. Among the Slovenian areas with the poorest natural conditions for agriculture we also rank White Carniola and Dry Carniola based on the karst indicator, which under the proposed eight European general biophysical criteria would be almost entirely omitted from areas less suitable for agriculture without this indicator.

In White Carniola and Dry Carniola there are 77 cadastral districts in which more than two-thirds of agricultural land is on karst rock. In Dry Carniola only one cadastral district - or 3.1\% of the territory or 3.0\% of agricultural land in the region - is not classified as an area less suitable for agriculture, and in White Carniola there are six such cadastral districts, encompassing $10.6 \%$ of the territory or $16.7 \%$ of the agricultural land.

Considering that a large part of Slovenia is omitted from areas less suitable for agriculture when the karst indicator is not taken into consideration, such an indicator is essential for consistent evaluation of Slovenian agricultural land and, connected with this, the opportunity to receive nearly $€ 10$ million in European Union subsidies.

As long as the European Union continues to consider mountain areas (Council regulation ... 1999, Article 18) as less-suitable areas, disregarding the karst indicator will not be so critical for Slovenia as a whole, 
Rok Ciglič, Mauro Hrvatin, Blaž Komac, Drago Perko, Karst as a criterion for defining areas less suitable for agriculture

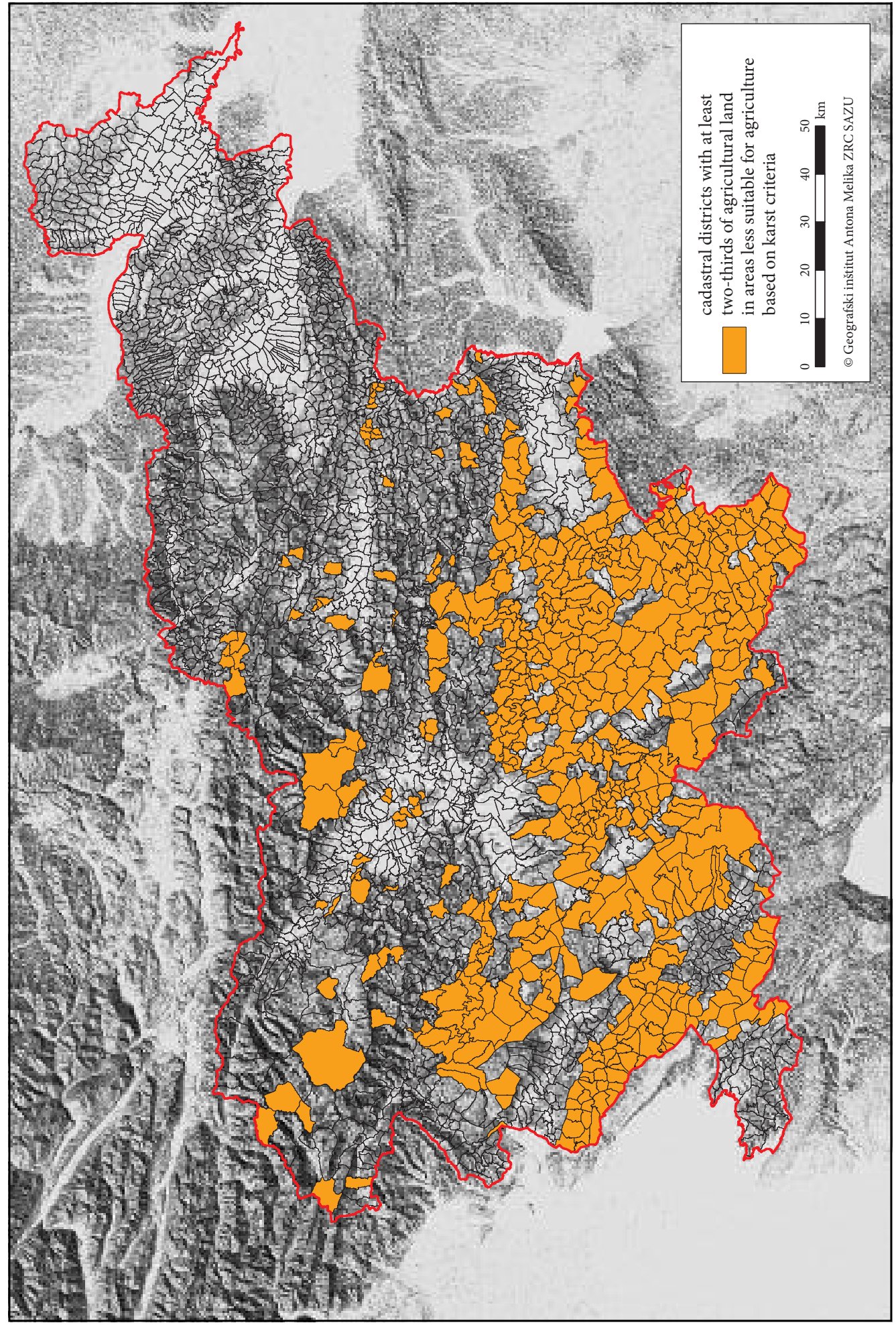


except for the karst regions of Dry Carniola and White Carniola, already mentioned several times, where farmers would not receive subsidies for farming less-suitable areas under clearly unfavorable conditions for agriculture. However, if the criteria for defining mountain areas, which encompass nearly three-quarters of Slovenia, are made stricter or even eliminated, the negative financial consequences for Slovenia and for many farmers would be very great, and this could have a significant effect on deterioration of the cultural landscape and depopulation of a considerable part of Slovenian territory.

The karst indicator therefore makes it possible, under new criteria for defining areas less suitable for agriculture, for Slovenia to preserve or justifiably even slightly increase its share of agricultural land classified as being in less-suitable areas, and thereby also the level of European funding for its development.

\section{Acknowledgement}

The paper is based on the research project Karst as a criterion for less favourable areas for agriculture in Slovenia, financed by Ministry of Agriculture, Forestry and Food.

\section{References}

Commission Communication: 'Towards a better targeting of the aid to farmers in areas with natural handicaps'. Internet: http://ec.europa.eu/agriculture/rurdev/lfa/comm/index_en.htm (18.6.2012)

Council regulation 1257/1999 on support for rural development from the European agricultural guidance and guarantee fund (EAGGF) and amending and repealing certain Regulations. Official Journal 160/80, 17. 5. 1999. Brussels. Internet: (15.6.2012).

Cunder, T. 2001: Območja z omejenimi dejavniki za kmetijstvo in reforma kmetijske politike v Sloveniji. Učinki reforme slovenske kmetijske politike, 1. konferenca DAES. Ljubljana.

Čar, J. 2001: Structural bases for shaping of dolines. Acta carsologica 30-2. Ljubljana.

Eliasson, Å., Jones, R. J. A., Nachtergaele, F., Rossiterd, D. G., Terresa, J.-M., Van Orshoven, J., van Velthuizen, H., Böttcher, K., Haastrup, P., Le Bas, C. 2010: Common criteria for the redefinition of Intermediate Less Favoured Areas in the European Union. Environmental Science \& Policy 13-8. Exeter. DOI: 10.1016/ j.envsci.2010.08.003

European Soil Database (v 2.0), European soil bureau network and the european commission, EUR 19945 EN, 2004. Internet: http://eusoils.jrc.ec.europa.eu/ESDB_Archive/ESDB/index.htm (15.6.2012).

Fridl, J., Gabrovec, M., Hrvatin, M., Perko, D. 1996: Geomorfološka inventarizacija območja Kraškega regijskega parka. Geografski inštitut Antona Melika ZRC SAZU. Ljubljana.

Gams, I. 1971: Podtalne kraške oblike. Geografski vestnik 42. Ljubljana.

Gams, I. 1974: Kras : zgodovinski, naravoslovni in geografski oris. Ljubljana.

Gams, I. 1987a: Lokev - zemlja in ljudje. Lokev skozi čas. Ljubljana.

Gams, I. 1987b: Classical Karst. Man's Impact in Dinaric Karst. Ljubljana.

Gams, I. 1991: Sistemi prilagoditve primorskega dinarskega krasa na kmetijsko rabo tal. Geografski zbornik 31. Ljubljana.

Gams, I. 2000: Doline morphogenetic processes from global and local viewpoints. Acta carsologica 29-2. Ljubljana.

Gams, I. 2003: Kras v Sloveniji v prostoru in času. Ljubljana.

Gams, I., Lovrenčak, F., Ingolič, B. 1971: Krajna vas : a study of the natural conditions and of agrarian land utilization on the Karst. Geografski zbornik 12. Ljubljana.

He, C., Xiong, K., Li, X., Cheng, X. 1998: Karst geomorphology and its agricultural implications in Guizhou, China. Fourth International Conference On Geomorphology - Bologna, Italy 1997. Supplements of Geografia Fisica e Dinamica Quaternaria, Volume III. Torino.

Hrovat, A. 1953: Kraška ilovica - njene značilnosti in vpliv na zgradbe. Ljubljana.

Hrvatin, M. 1985: Kmetijske melioracije na Krasu. Seminarska naloga, Oddelek za geografijo Filozofske fakultete Univerze v Ljubljani. Ljubljana.

Hrvatin, M., Komac, B., Perko, D., Zorn, M. 2006: Slovenia. Soil erosion in Europe. New York.

Kladnik, D. 1998a: Dinarski svet. Slovenija - pokrajine in ljudje. Ljubljana.

Kladnik, D. 1998b: Role and evaluation of settlements on karst in Slovenia. Acta carsologica 27-1. Ljubljana. 
Kladnik, D., Senegačnik, J. 1983: Opredelitev naselij s kraškim površjem. Elaborat, Geografski inštitut Antona Melika ZRC SAZU. Ljubljana.

Komac, B. 2003: Dolomite Relief in the Žibrše Hills/Dolomite relief in the Žibrše Hills. Acta geographica Slovenica 43-2. Ljubljana.

Komac, B., Natek, K., Zorn, M. 2008: Geografski vidiki poplav v Sloveniji. Ljubljana.

Komac, B., Zorn, M., 2005: Soil erosion on agricultural land in Slovenia - measurements of rill erosion in the Besnica valley. Acta geographica Slovenica 45-1. Ljubljana. DOI: 10.3986/AGS45103

Kranjc, A. 1986: Cerkniško jezero in njegove poplave. Geografski zbornik 25. Ljubljana.

LFA - Aid to farmers in less favoured areas. Rural development policy 2007-2013, Brussels. Internet: http://ec.europa.eu/agriculture/rurdev/lfa/index_en.htm (15.6.2012).

Litostratigrafska karta Slovenije. Geološki zavod Slovenije, naročnik ARSO, revizija 2011. Ljubljana.

Mihevc, A. 1998: Brezstropa jama pri Povirju in denudirane jame v okolici. Geografski obzornik 45-2. Ljubljana.

Mihevc, A. 2001: Speleogeneza Divaškega krasa. Ljubljana.

Mihevc, A. 2007: Nove interpretacije fluvialnih sedimentov na Krasu. Dela 28. Ljubljana.

Natek, K., Žumer, J., Ogrin, D., Topole, M., Hrvatin, M., Gabrovec, M. 1993: Geomorfološka inventarizacija kraškega roba. Geografski inštitut Antona Melika ZRC SAZU. Ljubljana.

Ogrin, D. 2002: Dry and wet years in Submediterranean Slovenia from the $14^{\text {th }}$ to the mid-19 ${ }^{\text {th }}$ century. Acta Universitatis Palackianae Olomucensis 37. Olomouc.

Pásztor, L., Szabó, J., Bakacsi, Z. 2010: Hungary according to common European biophysical criteria. World congress of soil science. Brisbane. Internet: http://www.iuss.org/19th\%20WCSS/Symposium/pdf/0436.pdf (15.6. 2012).

Perko, D. 2001: Analiza površja Slovenije s stometrskim digitalnim modelom reliefa. Geografija Slovenije 3. Ljubljana.

Perko, D. 2007: Morfometrija površja Slovenije. Georitem 3. Ljubljana.

Report on Testing of Biophysical Criteria for Areas with Natural Handicaps in Slovenia. Elaborat, Kmetijski inštitut Slovenije. Ljubljana, 2010.

Review of the Less Favoured Areas Scheme. House of Lords, European Union Committee - Minutes of Evidence. 2009, London. Internet: http://www.publications.parliament.uk/pa/ld200809/ldselect/ldeucom/98/9031802.htm (15.6.2012).

Šušteršič, F. 1984: Metoda morfometrije in računalniške obdelave vrtač. Acta carsologica 13. Ljubljana.

Towers, W., Birnie, R. 2009: Review of the Less Favoured Areas Scheme. Aberdeen. Internet: http://www.macaulay.ac.uk/policyrelevance/consultationresponses/2009/Evidence_to_House_of_Lords_LFA_Review_3 00109.pdf (15.6.2012).

Urich, P. B. 1989: Karst Management and Agricultural Development: Example from Bohol, Philippines. Geografiska Annaler. Series B. Human geography, 71-2. Stockholm. DOI: 10.2307\%2F490518

Van Orshoven, J., Terres, J. M., Eliasson, Å. 2008: Common bio-physical criteria to define natural constraints for agriculture in Europe. Ispra. Internet: http://agrienv.jrc.ec.europa.eu/Common\%20Criteria\% 20Fact\%20sheets.pdf (15.6.2012). DOI: 10.2788/96289

Van Orshoven, J., Terres, J. M., Toth, T. 2012: Updated Common bio-physical criteria to define natural constraints for agriculture in Europe. Ispra. Internet: http://agrienv.jrc.ec.europa.eu/Updated\%20Common\% 20Criteria\%20Fact\%20sheets.pdf (15.6.2012) DOI : 10.2788/91182

Volk, T., Rednak, M., Erjavec, E. 2010: Western Balkan agriculture and agricultural policy-Cross-Country overview and comparison. Agriculture in the Western Balkan Countries. Halle.

Zemljevid tipov kamnin. Geografski inštitut Antona Melika ZRC SAZU, različica 9. 12.2012. Ljubljana. 



\section{Kras kot kazalnik za določanje manj primernih območij za kmetijstvo}

DOI: $10.3986 /$ AGS52103

UDK: 91:631.111.2(497.4)

631.111.2:551.435.8(497.4)

COBISS: 1.01

IZVLEČEK: Predlagani kazalniki Evropske unije za določanje manj primernih območij za kmetijstvo v Sloveniji niso povsem primerni, saj bi z njihovim upoštevanjem izpadla nekatera izrazito in nedvoumno neugodna območja, na primer Suha krajina in Bela krajina, kmetje pa bi bili neupravičeno finančno oškodovani. $\mathrm{V}$ takem primeru ima vsaka država članica Evropske unije pravico predlagati dodaten kazalnik, s katerim zmanjša tovrstna neskladja. Glede na dejanske naravne razmere bi v Sloveniji neupravičeno izpadle predvsem nekatere kraške pokrajine, zato smo kot dodatni kriterij predlagali kazalnik kras, ki sloni na razporeditvi kraških, to je karbonatnih kamnin. S prostorskim prekrivanjem kraških kamnin in prsti smo ugotavljali, ali bi že bolj smiselna in manj toga uporaba evropskih kriterijev iz sklopa prsti lahko zadostovala za boljše rezultate pri določanju manj primernih območij za kmetijstvo v Sloveniji.

KLJUČNE BESEDE: Slovenija, Evropska unija, pokrajina, kras, kmetijstvo, kriteriji, manj primerna območja, območja z omejitvenimi dejavniki

Uredništvo je prejelo prispevek 18. maja 2012.

\section{NASLOVI:}

\section{Rok Ciglič}

Geografski inštitut Antona Melika

Znanstvenoraziskovalni center Slovenske akademije znanosti in umetnosti

Gosposka ulica 13, SI - 1000 Ljubljana, Slovenija

E-pošta: rok.ciglic@zrc-sazu.si

\section{Mauro Hrvatin}

Geografski inštitut Antona Melika

Znanstvenoraziskovalni center Slovenske akademije znanosti in umetnosti

Gosposka ulica 13, SI - 1000 Ljubljana, Slovenija

E-pošta: mauro@zrc-sazu.si

\section{dr. Blaž Komac}

Geografski inštitut Antona Melika

Znanstvenoraziskovalni center Slovenske akademije znanosti in umetnosti

Gosposka ulica 13, SI - 1000 Ljubljana, Slovenija

E-pošta: blaz.komac@zrc-sazu.si

\section{dr. Drago Perko}

Geografski inštitut Antona Melika

Znanstvenoraziskovalni center Slovenske akademije znanosti in umetnosti Gosposka ulica 13, SI - 1000 Ljubljana, Slovenija

E-pošta:drago@zrc-sazu.si 


\section{Kazalo}

$1 \quad$ Uvod

86

2 Kras

87

3 Metodologija

90

$4 \quad$ Rezultati za vsa zemljišča

95

5 Rezultati za kmetijska zemljišča

96

$6 \quad$ Sklep

98

7 Zahvala

98

8 Literatura

98 


\section{Uvod}

Leta 1999 je Evropska unija kot območja z naravnimi omejitvami za kmetijstvo določila tri pokrajinske tipe (Council regulation ... 1999, členi 17, 18, 19 in 20; Review ... 2009):

- gorska območja s kratko rastno dobo, strmimi pobočji in visoko lego (obsegajo 72,3\% površja Slovenije), - posebna prizadeta območja, ki so ogrožena zaradi posebnih okoliščin in je kmetijstvo nujno zaradi varovanja okolja, ohranjanja kulturne pokrajine, še posebej obal, in turistične izrabe (10,0\% površja Slovenije), - druga manj primerna območja s trajno nerodovitno prstjo (4,0 \% površja Slovenije).

To pomeni, da kar 86,3 \% površja Slovenije spada med območja z naravnimi omejitvami za kmetijstvo (Report ... 2010).

Leta 2005 je Evropska unija kar 91 milijonov ha ali 57 \% kmetijskih zemljišč opredelila kot manj primerna za kmetijstvo. Čeprav je na teh zemljiščih delalo približno 1,4 milijona ali le $13 \%$ kmetovalcev, namenja Evropska unija tem območjem znatna sredstva. Med letoma 2007 in 2013 je Evropski kmetijski usmerjevalni in jamstveni sklad EAGGF (European Agricultural Guidance and Guarantee Fund) tem območjem namenil 12,6 milijarde evrov, kar je 13,9\% sredstev, namenjenih razvoju podeželskih območij v Evropski uniji. Leta 2004 so se plačila za kmetijsko manj primerna območja gibala med 15 in 50 evrov na hektar v Španiji, Estoniji, Litvi, na Švedskem in Poljskem ter med 170 in 250 evrov na hektar v Avstriji, Belgiji, ter na Finskem in Malti. Povprečno plačilo za kmetijsko manj primerna območja v Evropski uniji je bilo 75 evrov na hektar (Eliasson s sodelavci 2010).

Za večino evropskih območij z omejitvenimi dejavniki za kmetijstvo je značilno, da kmetijstvo ne more zagotoviti primernega dohodka, da primanjkuje delovnih mest v nekmetijskih panogah in da so območja slabo povezana $z$ upravnimi središči. Posledice se kažejo v opuščanju slabših zemljišč, zatravljanju in zaraščanju z gozdom ter propadanju infrastrukture. S slabšanjem gospodarskih razmer pa se slabšajo tudi socialne razmere: manj je delovnih mest, prebivalci se izseljujejo, storitvene dejavnosti izginjajo (Cunder 2001). Podobno velja za Slovenijo.

Pred kratkim je Evropska unija dala večji poudarek območjem s slabimi podnebnimi razmerami in nizko rodovitnostjo prsti (LFA ... 2012). Za uvrstitev območij v različne kategorije omejitev po letu 2013 je predlagala osem splošnih biofizičnih kriterijev, ki pa naj bi veljali le za druga manj primerna območja (Council regulation ... 1999, člen 19). Predlagani kriteriji so (Commision ... 2012; Van Orshoven, Terres in Eliasson 2008; Elliason in ostali 2010; Van Orshoven, Terres in Toth 2012):

- nizka temperatura,

- vročinski stres,

- prepustnost prsti,

- tekstura in kamnitost (skeletnost) prsti,

- globina prekoreninjenosti prsti,

- kemične lastnosti prsti,

- vlažnostno ravnovesje prsti,

- naklon površja.

Kriteriji so združeni v tri sklope: prst, podnebje in relief oziroma oblikovanost površja.

V Sloveniji so na razpolago vektorski podatki, ki omogočajo določevanje kmetijsko manj primernih območij ter izračunavanje učinkov različnih biofizičnih kriterijev za celotno državno ozemlje. Tudi za celotno Evropsko unijo so na voljo ustrezni podatkovni sloji (European soil ... 2012), vendar pa imajo le redke države dovolj natančne podatke o prsti, reliefu, in podnebju (Pásztor, Szabó in Bakacsi 2010), kar še posebej velja za Bolgarijo in Romunijo (Elliason s sodelavci 2010). Zaradi takšne neenotnosti nekatere države nasprotujejo uvedbi enotnih meril za celotno Evropsko unijo (Towers in Birnie 2009).

Slovenija po številnih geografskih kazalnikih spada med države s slabimi naravnimi možnostmi za kmetijstvo. Na to kažejo že samo podatki za nekatere reliefne kazalnike, s katerimi so močno povezani skoraj vsi ostali naravni dejavniki. Kar 91,3\% površja Slovenije je na nadmorski višini več kot $200 \mathrm{~m}$ in $34,9 \%$ več kot $600 \mathrm{~m}$. Kar 83,7\% površja Slovenije ima naklon nad $2^{\circ}, 70,5 \% \operatorname{nad} 6^{\circ}$ in $50,7 \% \operatorname{nad} 12^{\circ}$ (Perko 2007). Ravnine so le na 15,3\% površja Slovenije (Perko 2001), pa še te ogrožajo poplave (redne poplave desetino ravnin, katastrofalne pa celo tretjino (Komac, Natek in Zorn 2008)), zato je tam le slaba četrtina vseh kmetijskih zemljišč v Sloveniji (Cunder 2001).

Kljub temu glede na navedenih osem evropskih kriterijev za določanje manj primernih območij za kmetijstvo pomemben del površja in kmetijskih zemljišč v Sloveniji, kjer so naravne razmere nedvoum- 
no omejitveni dejavnik, neupravičeno izpade. Najbolj očitno to velja za nekatere kraške pokrajine, na primer Suho krajino.

Ker članice Evropske unije lahko izjemoma predlagajo tudi dodatne kriterije oziroma kazalnike, smo na Geografskem inštitutu Antona Melika ZRC SAZU na podlagi značilnosti kraškega reliefa oblikovali nov, dodaten kazalnik, s katerim odpravljamo nekatere pomanjkljivosti evropskih kazalnikov, ki so se pokazale v pokrajinsko nadpovprečno pestri Sloveniji. S tem smo nadomestili tudi pomanjkanje nekaterih podatkov v Sloveniji za posamezne evropske kazalnike. Na podlagi tega kazalnika se med manj primerna območja za kmetijstvo uvrščajo tudi nekatera območja v Sloveniji, ki bi sicer po predlaganih evropskih kriterijih neupravičeno izpadla.

Kazalnik oziroma kriterij smo poimenovali kras ali zakraselost (angleško karst ali karstification). Uvršča se med reliefne kazalnike.

\section{Kras}

Zakraselost slovenskih pokrajin je izrazit omejevalni dejavnik za kmetijstvo, kar so geografi že večkrat poudarjali (Gams, Lovrenčak in Ingolič 1971; Gams 1974; Kladnik in Senegačnik 1983; Gams 1987a in 1991; Kladnik 1998a; Cunder 2001). Kladnik in Senegačnik (1983) sta pri določanju kraških pokrajin upoštevala posebne prvine kraške pokrajine, kot so golo površje, spremenljiva globina prsti, razgiban mikrorelief, vrtače, poplave kraških polj in podobno.

Zakraselost se navzven kaže v posebnem tipu oblikovanosti površja, nastalem predvsem s korozijo oziroma kemičnim raztapljanjem karbonatnih kamnin, predvsem apnenca in dolomita. Za kraške pokrajine je značilno kamnito površje z vrtačami, udornicami, uvalami, kraškimi polji, kraškimi ravniki ter suhimi in slepimi dolinami. V ljudskem jeziku označuje izraz kras golo kamnito zemljišče. Kras je najbolj izrazit na apnencu ali na območjih, kjer se apnenec menjava $\mathrm{z}$ drugimi karbonatnimi kamninami, manj izrazit pa je na ostalih karbonatnih kamninah ali tam, kjer se karbonatne kamnine menjavajo z nekarbonatnimi kamninami (Gams 1974; 2003).

Omejitveni dejavniki zaradi zakraselosti so:

- reliefne oblike: drobna reliefna razčlenjenost, predvsem z vrtačami in podobnimi korozijskimi oblikami;

- vodne razmere: pomanjkanje površinske vode zaradi hitrega odtoka vode skozi prepustne kraške kamnine, zato so pogoste suše in je večja nevarnost požarov;

- prsti (tla): nesklenjene, kamnite, plitve in glinaste, neenakomerno debele s pogostimi štrlečimi skalnimi izdanki in redkimi globljimi žepi;

- velika kraška raztresenost drobnih kmetijskih zemljišč, kar otežuje strojno obdelavo in prilagajanje zemljiškoposestne sestave sodobnimi agrotehničnimi ukrepi.

Slika 1: V ljudskem jeziku beseda kras pomeni golo kamnito pokrajino.

Glej angleški del prispevka.

Slika 2: Kamnito površje v okolici Sel pri Hinjah v Suhi krajini.

Glej angleški del prispevka.

Najznačilnejša in najštevilnejša depresijska reliefna oblika na krasu je vrtača, lijakasta korozijska kotanja s premerom do $50 \mathrm{~m}$ in globino do $10 \mathrm{~m}$, na dnu prekrita $\mathrm{z}$ debelejšo plastjo kraške gline, ki je pogosto netopni ostanek kemičnega raztapljanja karbonatnih kamnin. Poleg njih se pojavljajo še nekoliko večje uvale in kraška polja. Na kraških poljih so marsikje zelo obsežne poplave, na Cerkniškem polju, na primer, dosegajo površino $27 \mathrm{~km}^{2}$ (Kranjc 1986). Te so dodatni omejitveni dejavnik za kmetijstvo, saj se lahko zadržujejo tudi več mesecev. Med prvimi vodogradbenimi načrti na slovenskem krasu v 18. in 19. stoletju so bila prav dela za zmanjševanje in odpravljanje poplav na kraških poljih, vendar jih povečini niso izvedli ali dokončali (Gams 1974).

Zaradi prevlade podzemnega kraškega vodnega odtoka je površinska rečna mreža na krasu zelo redka. Na apneniškem krasu površinskih voda praviloma sploh ni, zato marsikje močno primanjkuje vode in so pogoste suše. Padavinska voda povečini neposredno odteka skozi razpoke v podzemlje, kjer oblikuje kraške votline. 
Preoblikovanje kraških kamnin je posledica njihove razpokanosti, prepustnosti in topnosti. Padavinska voda se v prsti navzame ogljikovega dioksida, pri čemer nastane šibka ogljikova kislina. Ta omogoča raztapljanje ali korozijo že na površini, deloma pa tudi v podzemlju. Zaradi nje se kraško površje počasi raztaplja in znižuje, v povprečju za nekaj mm v stoletju (Mihevc 1998; 2001; 2007).

Glede na prevladujočo karbonatno kamnino ločimo apneniški in dolomitni kras. Za apneniškega je značilno polgolo površje s prepletanjem skalnatih in s prstjo prekritih površin. Površje sestavljajo kopasti vrhovi in kraške kotanje. Ponekod je več kot 100 vrtač na $\mathrm{km}^{2}$, na manj čistih apnencih pa manj. Na Krasu, na primer, izstopa območje med Lipico in Sežano z gostoto kar 150 vrtač na km², pri Markovščini v Podgrajskem podolju pa jih je celo $240 \mathrm{na} \mathrm{km}^{2}$. Vrtače so pogostejše na razpokanih, tektonsko pretrtih območjih (Natek s sodelavci 1983; Šušterič 1984; Fridl s sodelavci 1996; Gams 2000; Čar 2001).

\section{Slika 3: Visoki skalni čoki pri Predmeji na Trnovskem gozdu.}

Glej angleški del prispevka.

Površje na apnencu je pogosto močno zakraselo, zato ga je tudi na nekoliko bolj uravnanih območjih težko obdelovati. Najmanjše kraške oblike so žlebiči, vzporedne drobne razjede, ki jih na goli skali v smeri največjega strmca izdolbe padavinska voda. Na podoben način vzdolž razpok in manj odpornih delov kamnine nastajajo tudi škraplje. Ponekod je kamnina tako močno zakrasela, da iz površja izstopajo številni skalni čoki, na pobočjih in slemenih pa je pogost kamnit svet $\mathrm{z}$ gruščem, imenovan griža (Gams 2003).

Apnenčeve skale, ki so na površju izpostavljene kemičnemu raztapljanju, imajo drobno razčlenjeno in hrapavo površino, apnenčeve skale, ki ležijo v prsti, pa imajo gladko oziroma zaobljeno površino. Zaradi tega lahko povsod, kjer je zaradi delovanja človeka erozija odnesla prst, ugotovimo, do katere višine je nekoč segal pokrov prsti (Gams 1971). Na ta način lahko sklepamo tudi o intenzivnosti erozije prsti, ki je na krasu pogosto spregledan geomorfni proces, saj voda vseskozi spira prst v podzemlje. Intenzivnosti spiranja prsti v podzemlje se pogosto premalo zavedamo. Posebej močno površinsko spiranje prsti je na strmih pobočjih ob nalivih, zato so opuščeni vinogradi pogosto prave kamnite puščave (Hrvatin s sodelavci 2006).

Erozijo prsti na krasu ugotavljamo posredno. Na ravnih kraških travnikih kamenje običajno moli od 20 do $30 \mathrm{~cm}$ iz zemlje in tolikšen je tudi učinek erozije. V vinogradih je erozija običajno mnogo večja. Domnevajo, da je bila erozija prsti na krasu v različnih zgodovinskih obdobjih različna. Po poseku gozda in ob prvem oranju je bila hitra, pozneje pa se je postopoma upočasnila. Na njivah in vinogradih jugovzhodne Slovenije je bilo ugotovljeno, da se prst v povprečju znižuje kar za $1 \mathrm{~cm}$ na leto (Hrovat 1953), povprečno pa se v Sloveniji letno sprošča od 3 do 5 ton prsti na hektar obdelovalnih zemljišč (Komac in Zorn 2005).

$\mathrm{Na}$ dolomitnem krasu so značilne kraške reliefne oblike redkejše, zato je tovrstni kras navadno manj izrazit od apneniškega. Značilne so plitve suhe dolinice, imenovane dolci. Poleg kemičnega raztapljanja kamnine sta na dolomitu pomembni še erozija in denudacija, zato je dolomitni kras marsikje podoben rečno-denudacijskemu reliefu in ga tudi imenujemo fluviokras (Komac 2003).

Slika 4: Značilna delana vrtača.

Glej angleški del prispevka.

Površje na karbonatnih kamninah je praviloma manj primerno za kmetijstvo. Obdelovanje zemlje je bilo zaradi drobne razčlenjenosti in kamnitosti površja vedno povezano $\mathrm{z}$ velikimi vlaganji v melioracije zemljišč. Zadostna debelina prsti, ki omogoča ureditev njiv, je le na dnu raznovrstnih kraških kotanj, po suhih in slepih dolinah ter na zakraselih planotah. $\mathrm{V}$ preteklosti so si ljudje skušali pridelovalne razmere izboljšati s trebljenjem kamenja s kraškega površja. Če so želeli kositi, so morali odstraniti kamenje $\mathrm{v}$ višini prsti, kjer pa so želeli orati, so morali poseči globlje v prst: 20 do $30 \mathrm{~cm}$ pri železnem plugu in do $50 \mathrm{~cm}$ pri rigolanju. Odbito kamenje so odvrgli v brezna in udornice, ga zmetali na kupe, ali iz njega zgradili suhe zidove (Gams 1987b).

Med najbolj razširjene melioracije na krasu spada urejanje vrtač, kjer so posegli tudi v njihovo obliko, zato so nastale tako imenovane »delane « vrtače; z velikimi posegi so nastali tudi delani travniki in orne terase s škarpami. Kako obsežno je bilo nekdaj trebljenje kraškega površja, lahko sklepamo po odbitem kamenju, ki je zloženo v škarpe in zidove, ponekod pa tudi v groblje. Takšni kamniti zidovi pogosto obdajajo delane vrtače, $\mathrm{v}$ katerih so bile skromne njivice. Na ta način so tudi varovali pridelek pred živino na 
paši. Pogosto so z vsakega $\mathrm{m}^{2}$ urejenega zemljišča odstranili več sto kg kamenja. Na Divaškem krasu ima tri četrtine v zidovih vgrajenih kamnov znake, da so bili odbiti (Gams 1991; Kladnik 1998b).

Dno delanih vrtač, ki imajo gladka pobočja in oster, nenaraven prehod pobočja v dno, so uravnali s prstjo, ki so jo nagrebli s pobočij in bližnje okolice. V njih so se najdlje ohranile njive in travniki. V preteklosti je bila ostra meja med otrebljenimi travniki in neotrebljenimi pašniki, kjer je kamenje zavzemalo tudi čez polovico površja. Delane vrtače so bile nekdaj pomemben del tradicionalne kulturne pokrajine, zdaj pa so povečini opuščene, oziroma so v njih travniki ali pašniki. Pogosto so jih ogradili s suhimi zidovi. Na katastrskem načrtu za vas Lokev na Krasu je bilo v 19. stoletju vrisanih kakšnih sto okroglastih ograd, ki so njivice varovale pred živalmi, spiranjem dežja in erozijskim delovanjem burje. V Krajni vasi je bila »delana« dobra polovica vseh vrtač (Gams 1987a).

Slika 5: Nekdanje ročno trebljenje krasa pri Suhorju v Beli krajini.

Glej angleški del prispevka.

Slika 6: Močno kamnita prst na njivi pri Lokvici na Krasu.

Glej angleški del prispevka.

Slika 7: Debele rdeče ilovnate gline pri Cikavi v Grosupeljski kotlini.

Glej angleški del prispevka.

Slika 8: Vsakoletna poplava na Planinskem polju.

Glej angleški del prispevka.

Slika 9: Navidez ravna Bela krajina je v resnici močno zakrasela in drobno razčlenjena pokrajina.

Glej angleški del prispevka.

Prst, ki prekriva kraško površje, je neenakomerno debela in iz nje pogosto štrli kamenje. Neenakomerna debelina prsti je največji omejitveni dejavnik za obdelovanje zemljišč na krasu. Na krasu prevladujejo rendzine in rjave pokarbonatne prsti, ki so pogosto močno izprane in vsebujejo malo karbonatov. Na apnencu z roženci je razvita bolj kisla in peščena prst, ki ji domačini pravijo kremenica, na čistejših apnencih pa ilovka. V osrednjem horizontu kremenice so pedologi pri raziskavah ugotovili od 56 do $75 \%$ kislega $\mathrm{SiO}_{2}$, v ilovki pa le od 49 do $57 \%$. Delež glinenih delcev v istem horizontu je približno enak: v kremenici od 56 do $75 \%$, v ilovki pa od 49 do $75 \%$. Ugodna lastnost kraške jerovice je velika množina koloidnih delcev, zaradi katerih lahko v sebi zadržuje večjo količino vode. To sposobnost v precejšnji meri zmanjšujejo večji kamniti delci, ki se v obdelanih kraških prsteh v veliki meri pojavljajo zaradi odbijanja kamenja ob melioracijah (Hrovat 1953; Gams 1974).

Ko so kmetje na polgolem krasu izkrčili gozd, je bila krčevina uporabna le za pašo. Danes se komaj zavedamo, da so morali kmetovalci večino površin za njive in travnike tako rekoč iztrgati krasu. Kako obsežno je bilo nekdaj trebljenje kraškega površja, lahko sklepamo po odbitem kamenju, zloženem v škarpe in zidove.

Do 2. svetovne vojne je prevladovalo ročno trebljenje, pri katerem so otrebili tudi do $200 \mathrm{~kg}$ kamenja na kvadratni meter zemljišča. Obseg takšnih melioracij je bil skromen in povečini omejen na zemljišča v neposredni bližini bivališč (Gams, Lovrenčak in Ingolič 1971).

Po 2. svetovni vojni se je začelo obdobje strojnega trebljenja ob pomoči bagrov in buldožerjev (Hrvatin 1985). Strojne melioracije travnika so časovno in delovno zahteven postopek, ki ponavadi obsega naslednje faze:

- sečnja gozda,

- izravnava površja s težkimi buldožerji,

- ročno trebljenje manjšega kamenja,

- strojni izkop in dovoz prsti,

- strojna izravnava prsti.

V trebanjskem delu Suhe krajine so na primer do leta 1990 pri čiščenju 2100 ha zemljišča odstranili $41.000 \mathrm{~m}^{3}$ kamenja oziroma $19,7 \mathrm{~m}^{3}$ ali 5 ton $\mathrm{z}$ vsakega hektarja. Pri strojnem odbijanju skal ostanejo v prsti številni skalni delci, odkruški, ki zmanjšujejo sposobnost prsti za zadrževanje vode in pospešujejo sušnost (Gams 2003). 
Ker so karbonatne kamnine prepustne za vodo, kmetijska zemljišča v vegetacijski dobi pogosto prizadenejo suše. Pomanjkanje površinske vodne mreže onemogoča kakršnokoli obliko namakanja. Sušnost prsti dodatno povečuje kamninski drobir, ki je zaradi trebljenja pogosto pomešan v prsti. Zaradi suše so na kraških tleh pogostejši tudi požari (Ogrin 2002).

V literaturi lahko zasledimo tudi opise manj primernih naravnih razmer za kmetovanje na krasu v drugih državah. He in sodelavci (1998) so navedli številne ovire, s katerimi se srečuje kmetijstvo v kitajski pokrajini Guizhou. Med njimi so izpostavili nizko alkalnost prsti, slabo rodovitnost, počasno tvorjenje prsti, tanek sloj prsti in njeno veliko erozijo, ki je največja v bolj namočenih predelih, poveča pa jo tudi čezmerna sečnja. Prav tako so izpostavili dostopnost do vodnih virov, ki je zaradi podzemnega odtekanja vode zelo otežena in zato »... voda postane tako draga kot je nafta ... «. Tudi v primeru omenjene kitajske pokrajine je značilno, da je delež kmetijskih zemljišč majhen (od 5 do $10 \%$ ). Urich (1989) je opozoril, da je načrtovanje na območju tropskega krasa drugačno od drugih tropskih območij in zahteva posebne ukrepe. Izpostavil je zagotavljanje podzemnih vodnih zalog, zadrževanje površinske vode, nenadzorovano odlaganje odpadkov in splošno ranljivost ekosistema. Zaradi gorovja in/ali kraškega površja imajo slabše razmere za kmetijstvo tudi države na zahodu Balkanskega polotoka (Volk, Rednak in Erjavec 2010).

\section{Metodologija}

Za opredeljevanje kazalnika kras, določanje manj primernih območij za kmetijstvo glede na kazalnik kras in ugotavljanje povezanosti med kraškimi kamninami in prstmi smo najprej določili kraške litološke in pedološke enote.

Visoka stopnja povezanosti med kraškimi kamninami, na katerih temelji kazalnik kras, in kraškimi prstmi, ki zadoščajo pogojem za kriterije iz sklopa prsti, bi namreč pomenila, da bi se sporna (izpadla) kmetijska zemljišča že z ustrezno (smiselno) uporabo litoloških enot lahko uvrstila med manj primerna območja za kmetijstvo, zato uvedba novega kriterija, torej kazalnika kras, ne bi bila nujna. Za vsako posamezno pedološko enoto je namreč mogoče ugotoviti, ali v splošnem (v povprečju) zadošča pogojem vsaj enega od kriterijev iz skupine prsti (prepustnost, tekstura in kamnitost, globina prekoreninjenosti, kemične lastnosti in vlažnostno ravnovesje prsti) za uvrstitev $k$ manj primernim območjem za kmetijstvo. Pri kazalniku globina prekoreninjenosti prsti je na primer mejna vrednost $30 \mathrm{~cm}$, kar pomeni, da vsi tipi prsti oziroma pedološke enote, pri katerih globina prekoreninjenosti običajno ne presega $30 \mathrm{~cm}$, ustrezajo merilom za uvrstitev k manj primernim območjem za kmetijstvo. Taki mejni merili sta še, na primer, da morajo delci gline clay presegati $60 \%$ ali da morajo kamniti izdanki segati več kot $15 \mathrm{~cm}$ iznad prsti.

Vektorski podatkovni sloj s kraškimi kamninami (Zemljevid tipov kamnin ... 2012) smo pripravili na podlagi vektorskega sloja Litološka karta 1:250.000, ki smo jo izdelali na podlagi vektorske Litostratigrafske karte Slovenije (Litostratigrafska karta ... 2007; revizija 2011), ki jo je po naročilu Agencije Republike Slovenije za okolje predvsem na podlagi vektoriziranih geoloških kart Slovenije v merilu 1:25.000 izdelal Geološki zavod Slovenije.

Kraške kamnine sestavljajo naslednje enote:

- masiven apnenec,

- plastovit apnenec,

- ploščast apnenec,

- litotamnijski apnenec,

- apnenčev konglomerat,

- apnenec in dolomit,

- kraška ilovica,

- dolomit,

- karbonatno-klastične kamnine. 
Acta geographica Slovenica, 52-1, 2012

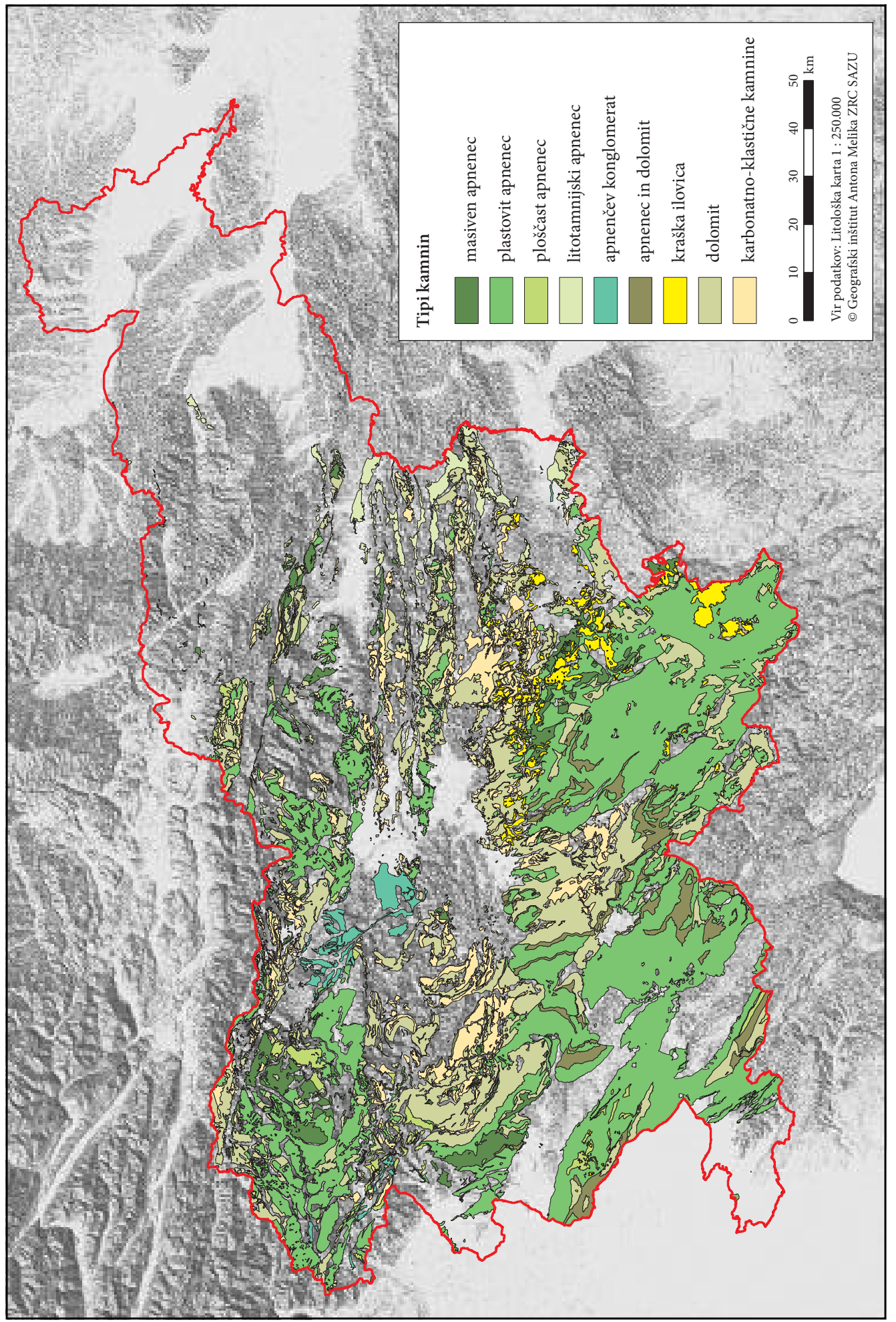


Rok Ciglič, Mauro Hrvatin, Blaž Komac, Drago Perko, Kras kot kazalnik za določanje manj primernih območij za kmetijstvo

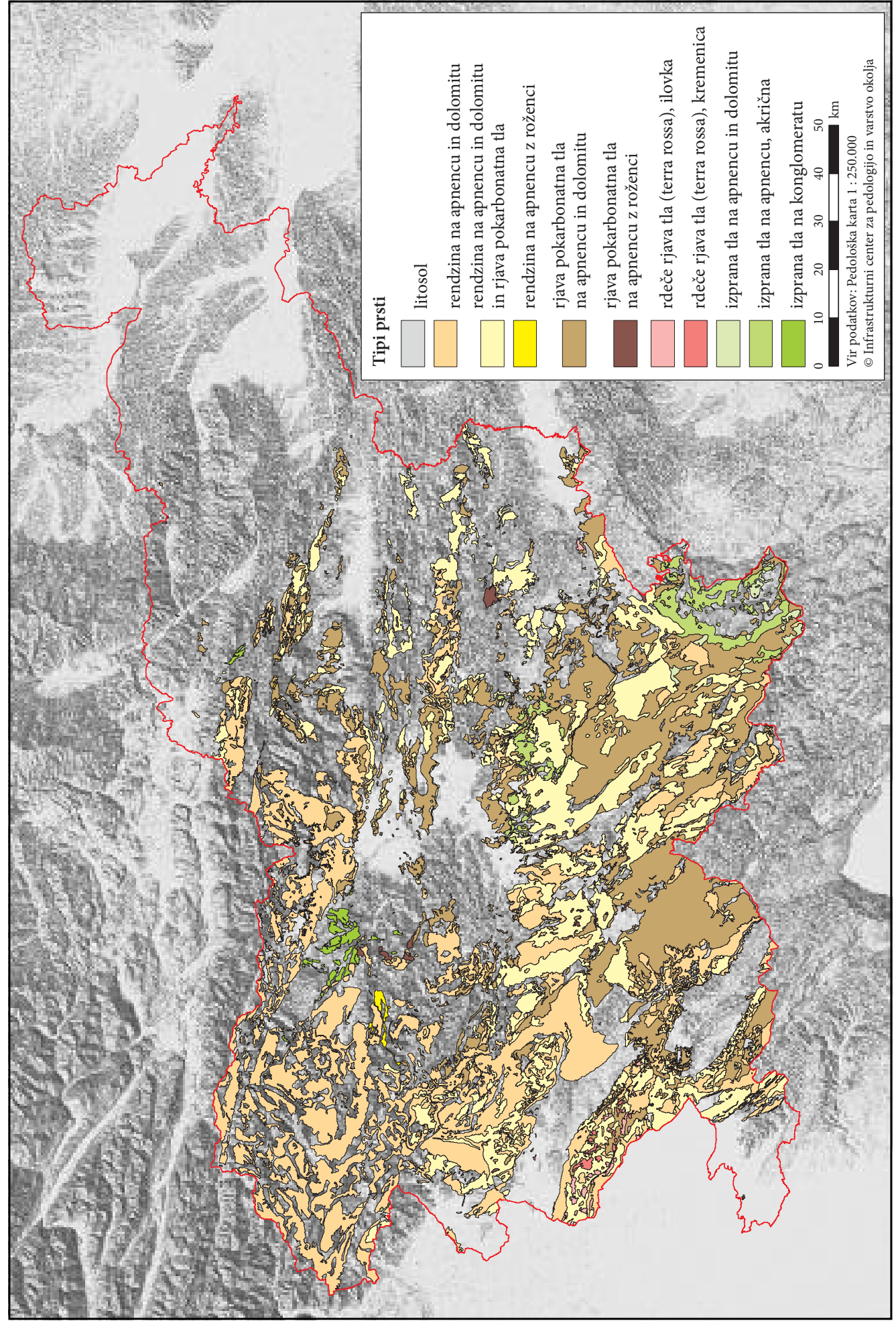




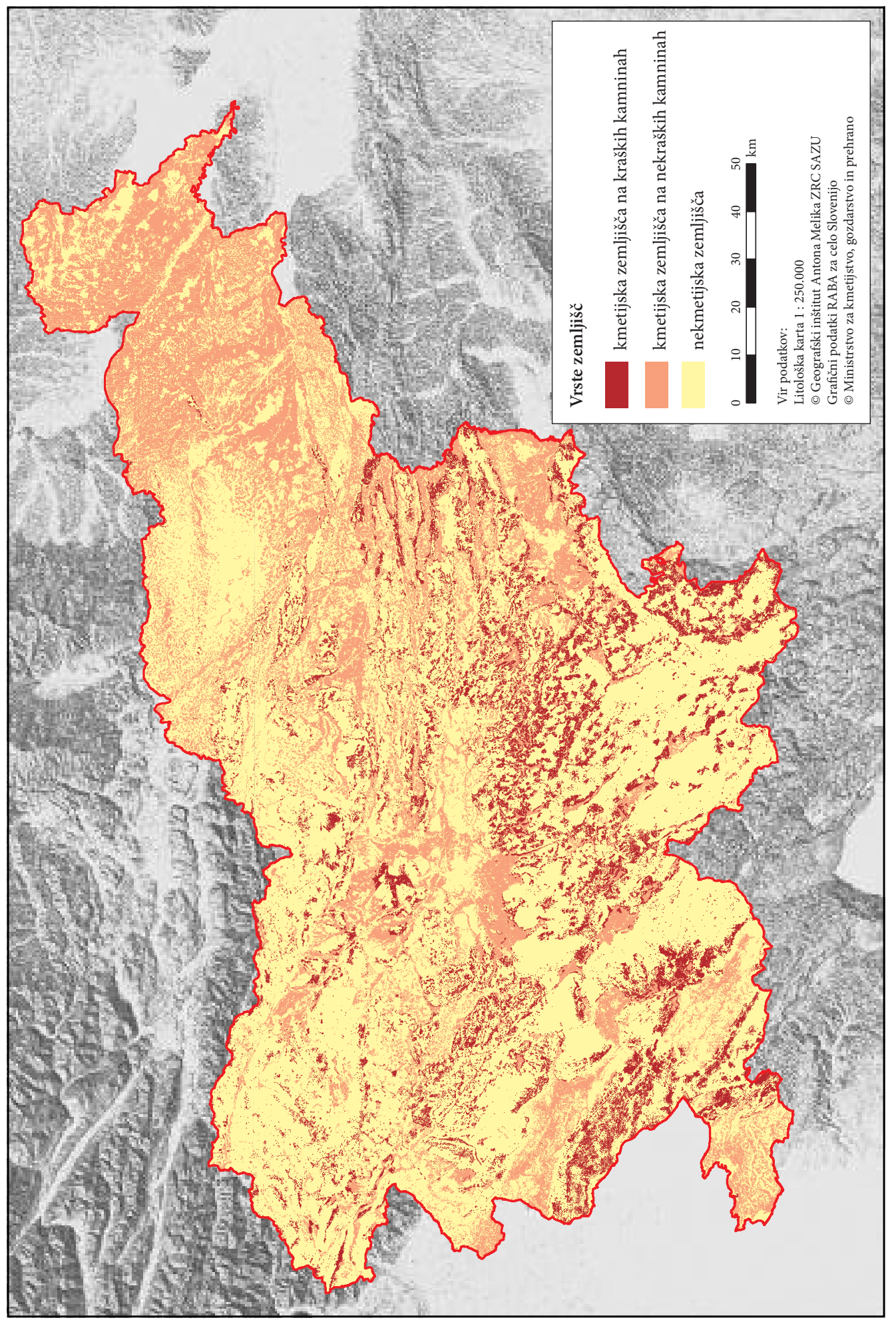




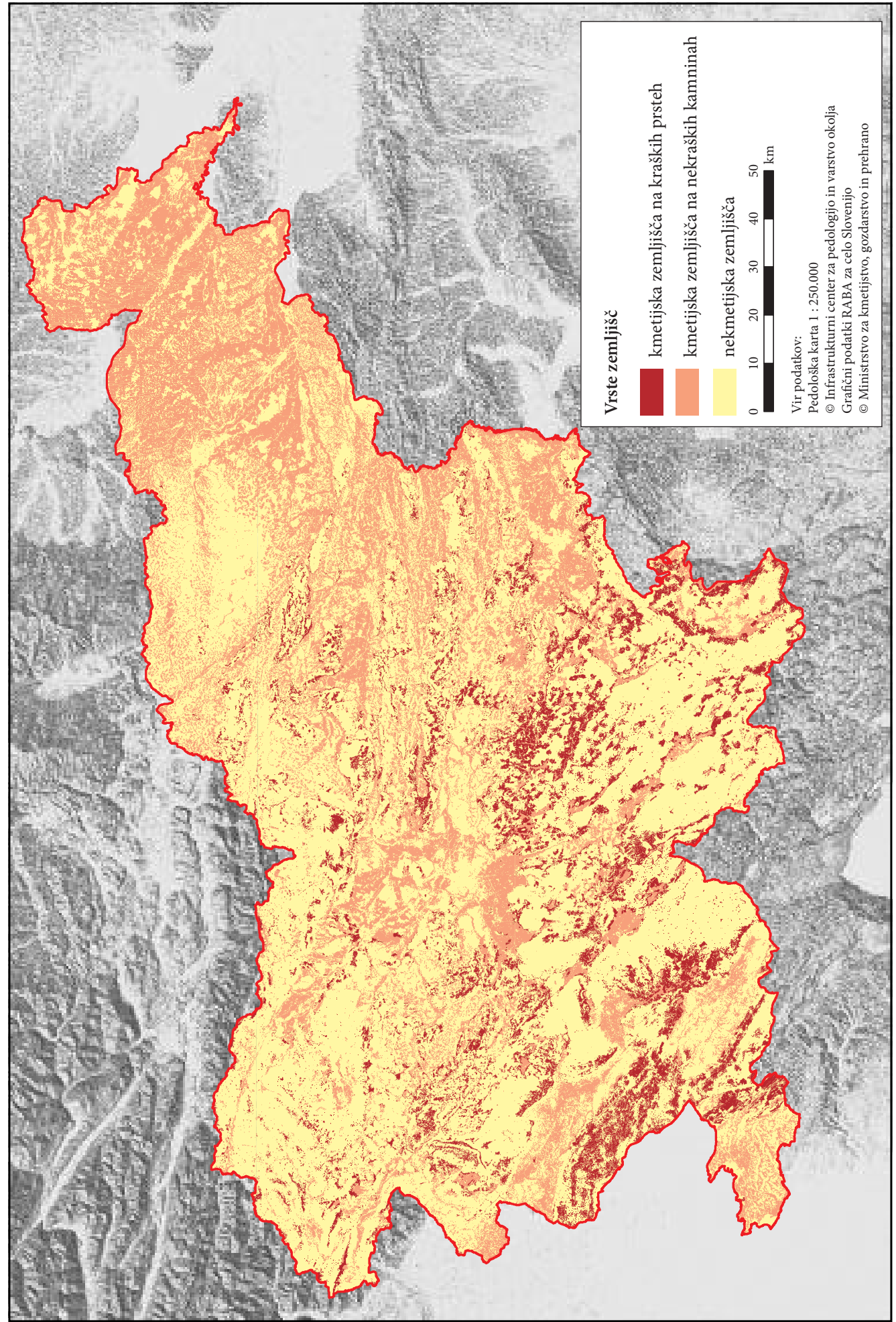


Vektorski podatkovni sloj s kraškimi prstmi smo pripravili na podlagi vektorskega sloja Pedološka karta $1: 250.000$, ki so ga izdelali v Infrastrukturnem centru za pedologijo in varstvo okolja (TIS/ICPVO Infrastrukturni center za pedologijo in varstvo okolja, Biotehniška fakulteta Univerze v Ljubljani, Ljubljana 1999-2011). Izbrali smo tiste prsti, ki s svojimi značilnostmi ustrezajo merilom vseh petih evropskih splošnih biofizičnih kriterijev iz sklopa prsti.

Kraške prsti sestavljajo naslednje enote:

- litosol,

- rendzina na apnencu in dolomitu,

- rendzina na apnencu in dolomitu ter rjava pokarbonatna tla,

- rendzina na apnencu z roženci,

- rjava pokarbonatna tla na apnencu in dolomitu,

- rjava pokarbonatna tla na apnencu $z$ roženci,

- rdeče rjava tla (terra rossa), ilovka,

- rdeče rjava tla (terra rossa), kremenica,

- izprana tla na apnencu in dolomitu,

- izprana tla na apnencu, akrična,

- izprana tla na konglomeratu.

Pripravili smo kontingečno tabelo, ki prikazuje, koliko kraških prsti je na kraških kamninah in koliko na nekraških kamninah, oziroma koliko kraških kamnin je pod kraškimi prstmi in koliko pod nekraškimi prstmi (preglednica 1).

Na temelju frekvenčne distribucije smo najprej izračunali statistični kazalnik $h i^{2}$, iz njega pa statistična kazalnika $r^{2}$ (determinacijski koeficient) in $r$ (korelacijski koeficient), ki prikazujeta stopnjo povezanosti.

Na podoben način smo pripravili tudi kontingenčno tabelo samo za kmetijska zemljišča s kraškimi kamninami in prstmi (preglednica 2).

\section{Rezultati za vsa zemljišča}

V Sloveniji, ki meri $20.273 \mathrm{~km}^{2}$, je $9142 \mathrm{~km}^{2}(45,1 \%)$ površja s kraškimi kamninami in $7975 \mathrm{~km}^{2}(39,3 \%)$ s kraškimi prstmi.

Že sama razporeditev kraških kamnin in kraških prsti kaže na njihovo močno povezanost. Iz kontingečne tabele (preglednica 1) je razvidno, da je kar 91,8\% kraških prsti na kraških kamninah in da je 85,2 \%

Preglednica 1: Kontingenčna tabela s kraškimi kamninami in prstmi.

\begin{tabular}{lccc}
\hline kamnine in prsti & $\begin{array}{c}\text { nekraške kamnine } \\
\text { ha }\end{array}$ & $\begin{array}{c}\text { kraške kamnine } \\
\text { ha }\end{array}$ & $\begin{array}{c}\text { skupaj } \\
\text { ha }\end{array}$ \\
\hline nekraške prsti & 1.047 .467 & 182.290 & 1.229 .757 \\
kraške prsti & 65.574 & 731.955 & 797.529 \\
skupaj & 1.113 .041 & 914.245 & 2.027 .286 \\
\hline & $\%$ & $\%$ & $\%$ \\
nekraške prsti & 85,2 & 14,8 & 100,0 \\
kraške prsti & 8,2 & 91,8 & 100,0 \\
skupaj & 54,9 & 45,1 & 100,0 \\
\hline nekraške prsti & 94,1 & 19,9 & 60,7 \\
kraške prsti & 5,9 & 80,1 & 39,3 \\
skupaj & 100,0 & 100,0 & 100,0 \\
\hline nekraške prsti & 51,7 & 9,0 & 60,7 \\
kraške prsti & 3,2 & 36,1 & 39,3 \\
skupaj & 54,9 & 45,1 & 100,0 \\
\hline statistični kazalniki & & & \\
hi & iz 32.365 .580 celic & & $18.513 .792,64$ \\
$r^{2}$ & & & 0,5708 \\
$r$ & & & 0,7555 \\
\hline
\end{tabular}


nekraških prsti na nekraških kamninah. Hkrati je 80,1 \% kraških kamnin pod kraškimi prstmi in kar 94,1 \% nekraških kamnin pod nekraškimi prstmi.

Skupaj 36,1 \% Slovenije sestavlja kombinacija kraških kamnin in kraških prsti, 51,7\% Slovenije pa je kombinacija nekraških kamnin in nekraških prsti, kar je skupaj kar 87,8\%. To pomeni, da glede na uporabljene podatke na vsega $12,2 \%$ površja Slovenije ni navedenih kombinacij, ali drugače, da se komaj na desetini površja Slovenije prepletajo kraške kamnine in nekraške prsti oziroma nekraške kamnine in kraške prsti.

Visoko stopnjo povezanosti potrjuje tudi korelacijski koeficient $r$, ki smo ga na podlagi več kot 32 milijonov kvadratnih celic z osnovnico $25 \mathrm{~m}$ izračunali iz $h i^{2}$. Vrednost korelacijskega koeficienta $r$ je 0,7555 . Tako $h i^{2}$ kot $r$ (preglednica 1) znatno presegata mejo njunih teoretičnih vrednosti pri tveganju 0,01, zato lahko s tveganjem $1 \%$ oziroma $\mathrm{z}$ gotovostjo $99 \%$ sklepamo, da sta prostorski razporeditvi kraških kamnin in kraških prsti statistično značilno povezani.

\section{Rezultati za kmetijska zemljišča}

V prejšnjem poglavju smo ugotavljali prostorsko povezanost med kraškimi kamninami in prstmi za vsa

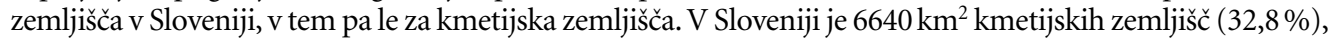
od tega jih je $1927 \mathrm{~km}^{2}(29,0 \%)$ na kraških kamninah in $1438 \mathrm{~km}^{2}(21,7 \%)$ na kraških prsteh.

Že sama razporeditev kraških kamnin in kraških prsti kaže na njihovo močno povezanost. Iz kontingečne tabele (preglednica 2) je razvidno, da je kar 90,8 \% kraških prsti na kraških kamninah in da je 88,1 \% nekraških prsti na nekraških kamninah. Hkrati je 67,8\% kraških kamnin pod kraškimi prstmi in kar 97,2\% nekraških kamnin je pod nekraškimi prstmi. To so torej razmerja, ki veljajo za kmetijska zemljišča na kraških kamninah in prsteh v Sloveniji.

Visoko stopnjo povezanosti potrjuje tudi korelacijski koeficient $r$, ki smo ga na podlagi več kot 32 milijonov kvadratnih celic z osnovnico $25 \mathrm{~m}$ izračunali iz $h i^{2}$. Vrednost korelacijskega koeficienta je $0,7159$. Tako $h i^{2}$ kot $r$ (preglednica 2) znatno presegata mejo njunih teoretičnih vrednosti pri tveganju 0,01 , zato lahko s tveganjem $1 \%$ oziroma z gotovostjo $99 \%$ sklepamo, da sta prostorski razporeditvi kraških kamnin in kraških prsti statistično značilno povezani.

To pomeni, da sta prostorski razporeditvi kraških kamnin in prsti statistično značilno povezani tako v celoti, za vsa zemljišča $(0,7555)$, kot tudi samo za kmetijska zemljišča $(0,7159)$, oziroma, da med korelacijskima koeficientoma ni pomembne razlike.

Preglednica 2: Kontingenčna tabela kmetijskih zemljišč s kraškimi kamninami in prstmi.

\begin{tabular}{lccc}
\hline kamnine in prsti & $\begin{array}{c}\text { nekraške kamnine } \\
\text { ha }\end{array}$ & $\begin{array}{c}\text { kraške kamnine } \\
\text { ha }\end{array}$ & $\begin{array}{c}\text { skupaj } \\
\text { ha }\end{array}$ \\
\hline nekraške prsti & $458.045,19$ & $62.114,69$ & $520.159,88$ \\
kraške prsti & $13.184,19$ & $130.611,81$ & $143.796,00$ \\
skupaj & $471.229,38$ & $192.726,50$ & $663.955,88$ \\
\hline & $\%$ & $\%$ & $\%$ \\
nekraške prsti & 88,1 & 11,9 & 100,0 \\
kraške prsti & 9,2 & 90,8 & 100,0 \\
skupaj & 71,0 & 29,0 & 100,0 \\
\hline nekraške prsti & 97,2 & 32,2 & 78,3 \\
kraške prsti & 2,8 & 67,8 & 21,7 \\
skupaj & 100,0 & 100,0 & 100,0 \\
\hline nekraške prsti & 69,0 & 9,4 & 78,3 \\
kraške prsti & 2,0 & 19,7 & 21,7 \\
skupaj & 71,0 & 29,0 & 100,0 \\
\hline statistični kazalniki & & & \\
hi $^{2}$ & iz 32.365 .580 celic & & $5.445 .170,517$ \\
$r^{2}$ & & & 0,5126 \\
$r$ & & & 0,7159 \\
\hline
\end{tabular}


Acta geographica Slovenica, 52-1, 2012

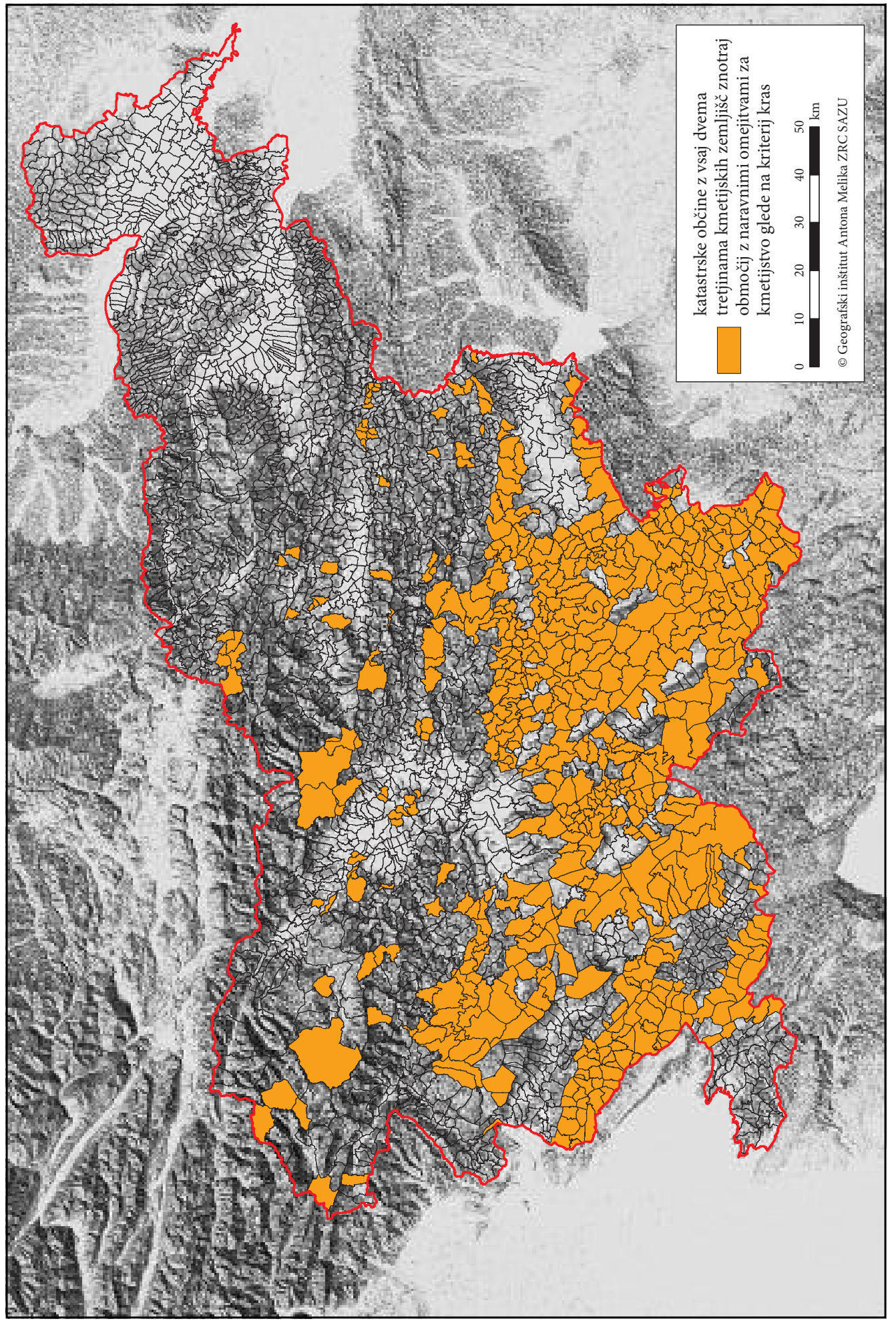




\section{Sklep}

Pri celovitem vrednotenju kmetijskih zemljišč moramo upoštevati kazalnik kras, saj so za kraško površje značilne posebne pridelovalne razmere. Kljub dokaj veliki namočenosti krasa v Sloveniji vodoprepustnost kraških kamnin in prevladujoč podzemni odtok otežujeta preskrbo z vodo. Zaradi nizke vsebnosti netopnih sestavin v kamnini na apnencu prst nastaja počasneje kot na drugih kamninah, poleg tega je na kraških goličavah pogosta erozija. Zato je površje na kraških kamninah prekrito z razmeroma tanko prstjo, delež kamninskega gradiva v njej pa je izredno velik. Kmetovalci so morali že od nekdaj izboljševati prst (na primer s trebljenjem kamenja), da bi si vsaj ponekod zagotovili boljše razmere za kmetovanje.

Kmetovanje otežuje tudi velika ranljivost kraškega ekosistema. Morebitna pretirana raba mineralnih gnojil in zaščitnih sredstev je lahko zelo nevarna, saj se snovi v krasu spirajo neposredno v podzemlje, od tam pa prehajajo v kraške izvire, ki so na krasu edini vir pitne vode.

Razumljivo je, da je upoštevanje omenjenih značilnosti kraških kamnin nujno pri vrednotenju slovenskih kmetijskih zemljišč. Kazalnik kras, ki smo ga opredelili, temelji na litološki sestavi površja in upošteva območja kraških kamnin, to je kamnin, na katerih je nastal kras. Z njim smo izračunali delež kraškega površja v slovenskih katastrskih občinah ter ugotovili visoko stopnjo povezanosti kraških kamnin in kraških prsti. Slednje upravičuje možnost, da bi kazalnik lahko temeljil tudi na prikazu kraških prsti, določenih s pomočjo pedološke karte.

Med manj primerna območja za kmetijstvo naj bi se v celoti uvrstile tiste katastrske občine, kjer sta vsaj dve tretjini kmetijskih zemljišč na kraških kamninah. V Sloveniji je med 2697 katastrskimi občinami 561 ali petina $(20,8 \%)$ takih, v katerih sta glede na kazalnik kras vsaj dve tretjini kmetijskih zemljišč znotraj manj primernih območij za kmetijstvo. Skupna površina kmetijskih zemljišč v teh 561 občinah je 148.677 ha (od tega jih je na kraških kamninah 133.122 ha), kar je 22,4 \% vseh kmetijskih zemljišč v Sloveniji. Med slovenske pokrajine $\mathrm{z}$ najslabšimi naravnimi razmerami za kmetijstvo uvrščamo tudi Belo krajino in Suho krajino, ki po predlaganih osmih evropskih splošnih biofizičnih kriterijih skoraj v celoti izpadeta iz manj primernih območij za kmetijstvo, glede na kazalnik kras pa ne.

V Beli krajini in Suhi krajini je 77 katastrskih občin, kjer sta več kot dve tretjini kmetijskih zemljišč na kraških kamninah. V Suhi krajini le ena katastrska občina ali 3,1 \% ozemlja oziroma 3,0 \% kmetijskih zemljišč v pokrajini ne spadajo med manj primerna območja za kmetijstvo, v Beli krajini pa je takšnih 6 katastrskih občin, ki obsegajo 10,6\% ozemlja oziroma 16,7 \% kmetijskih zemljišč.

Glede na to, da velik del Slovenije z neupoštevanjem kazalnika kras izpade iz manj primernih območij za kmetijstvo, je tovrsten kazalnik nujen za dosledno vrednotenje slovenskih kmetijskih zemljišč in s tem povezane možnosti prejemanja skoraj desetih milijonov evrov subvencij Evropske unije.

Dokler bo Evropska unija k manj primernim območjem štela gorska območja (Council regulation ... 1999, člen 18), neupoštevanje kazalnika kras za Slovenijo kot celoto ne bi bilo tako kritično, razen za že večkrat omenjeni izrazito kraški pokrajini Suha krajina in Bela krajina, kjer kmetje kljub izrazito neugodnim možnostim za kmetijstvo ne bi prejemali subvencij za kmetovanje na manj primernih območjih. Če pa bi se kriteriji za določevanje gorskih območij, kamor spadajo skoraj tri četrtine Slovenije, zaostrili ali celo odpravili, bi bili negativni finančni učinki za Slovenijo in številne kmete zelo veliki, to pa bi lahko pomembno vplivalo na propadanje kulturne pokrajine in depopulacijo znatnega dela slovenskega ozemlja.

Kazalnik kras torej omogoča, da Slovenija tudi ob novih kriterijih za določanje manj primernih območij za kmetijstvo ohrani ali upravičeno celo malenkostno poveča delež kmetijskih zemljišč na manj primernih območjih, s tem pa tudi višino evropskih sredstev za njihov razvoj.

\section{Zahvala}

Prispevek temelji na raziskovalni nalogi Kras kot kazalnik manj ugodnih območij za kmetijstvo v Sloveniji, ki jo je financiralo Ministrstvo za kmetijstvo, gozdarstvo in prehrano.

\section{Literatura}

Glej angleški del prispevka. 